University of Rhode Island

DigitalCommons@URI

Open Access Master's Theses

2003

\title{
A Study of Stainless Steel Reinforement to Replace Conventional Carbon Steel Reinforcement
}

Jalal Alsarraf

University of Rhode Island

Follow this and additional works at: https://digitalcommons.uri.edu/theses

\section{Recommended Citation}

Alsarraf, Jalal, "A Study of Stainless Steel Reinforement to Replace Conventional Carbon Steel

Reinforcement" (2003). Open Access Master's Theses. Paper 1111.

https://digitalcommons.uri.edu/theses/1111

This Thesis is brought to you for free and open access by DigitalCommons@URI. It has been accepted for inclusion in Open Access Master's Theses by an authorized administrator of DigitalCommons@URI. For more information, please contact digitalcommons-group@uri.edu. 
A STUDY OF STAINLESS STEEL REINFORCEMENT TO REPLACE CONVENTIOAL CARBON STEEL REINFORCEMENT

\author{
BY \\ JALAL ALSARRAF
}

A THESIS SUBMITTED IN PARTIAL FULFILMENT OF THE REQUIREMENTS FOR THE DEGREE OF MASTER OF SCIENCE

IN

OCEAN ENGINEERING

UNIVERSITY OF RHODE ISLAND

2003 
MASTER OF SCIENCE THESIS

OF

JALAL ALSARRAF

APPROVED:

Thesis Committee

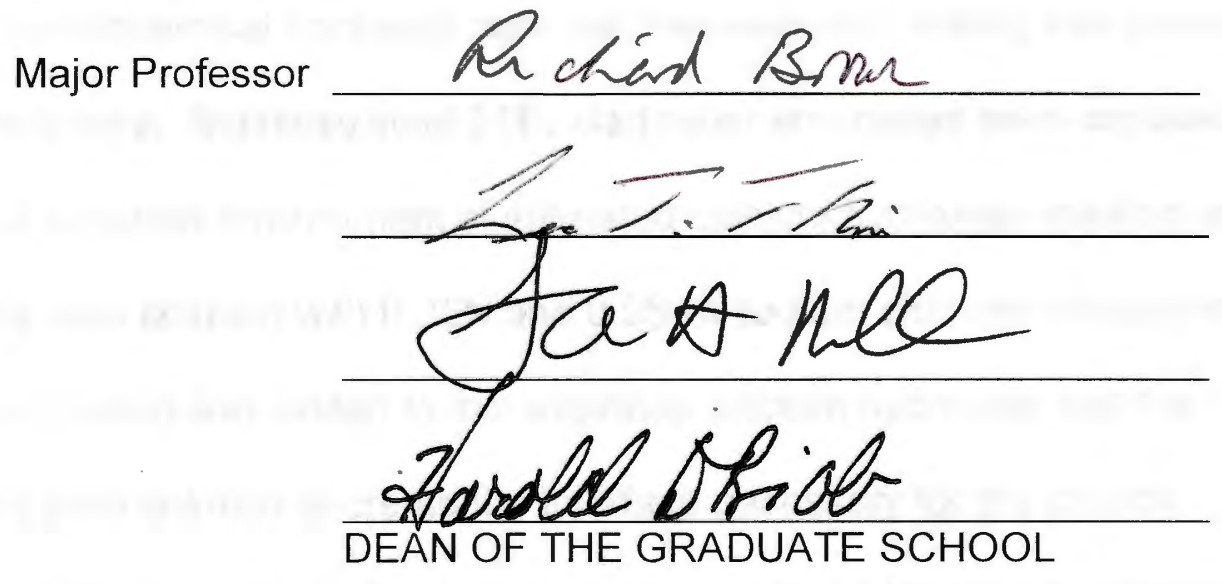

UNIVERSITY OF RHODE ISLAND 


\section{ABSTRACT}

Corrosion of reinforcing steel in concrete has become a major factor in reducing the service life of vital transportation and building systems due to the exposure of chloride ions. The needs of this well known phenomenon for cost effective system for protection against corrosion has become increasingly clear. Thus, corrosion behavior of stainless 316 L clad reinforcing steel was investigated in this study. The object of the present investigation was to develop quantitative data that would accurately access the pitting and crevice corrosion susceptibility of stainless steel $316 \mathrm{~L}$ rebar in concrete environments.

Electrochemical corrosion potential measurement testing was conducted to all specimens. Stainless steel $316 \mathrm{~L}$ clad rebar and plates were exposed in a simulated concrete environment of saturated calcium hydroxide solution and simulated pore solution with $0.25 \mathrm{~N}$ and $0.5 \mathrm{~N}$ of sodium chloride concentrations. A five gm of sand was added to the saturated calcium hydroxide and the simulated pore solution to create the interface necessary for the crevice corrosion. The potential of the system compared to a saturated electrode calomel reference was monitored to evaluate corrosion performance as a function of the exposure time. The effect of calcium nitrite $(\mathrm{DCl})$ inhibitor on crevice corrosion of stainless steel clad rebar was investigated. Rebar with cut ends were suspended in simulated pore solution with 0.25 and $0.5 \mathrm{~N}$ of sodium chloride having additions of $0.25 \mathrm{~N}$ and $0.5 \mathrm{~N} \mathrm{DCl}$. The time to corrosion was 
measured by potential change. Results indicated that specimens with calcium nitrite corrosion inhibitor exhibited the best corrosion protection results in corrosive conditions with essential minimum concentration of calcium nitrite for protecting the rebar. End caps can protect end cut corrosion of stainless steel rebar. 


\section{ACKNOWLEDGEMENTS}

I am extremely grateful to my major professor Dr. Richard Brown in the Chemical Engineering Department for giving me this opportunity to work on this research project. I thank him for his guidance and supervision during my studies. I would like also to express my sincere appreciation to Dr. James Miller and Dr. Thiem Leon for serving my thesis committee and accommodating me within their time schedule. Thanks are also expressed to Dr. K. Wayne Lee for spending his time to be the chair person of my thesis defense.

There are many others who have contributed, I can't name them all, but their support has a deciding impact in the successful completion of this thesis. I thank all those unnamed persons.

At last, I would like to take this opportunity to express my greatest appreciation to all my family for giving me the strength to continue my study away from home. 


\section{PREFACE}

This master's thesis is written in a standard form according to the guidelines of the graduate school in University of Rhode Island. All tables and graphs were either a computer generated or scanned images. 


\section{TABLE OF CONTENT}

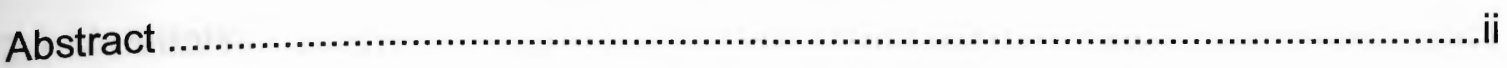

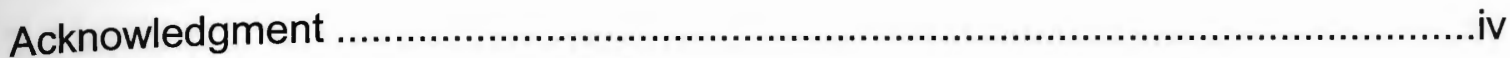

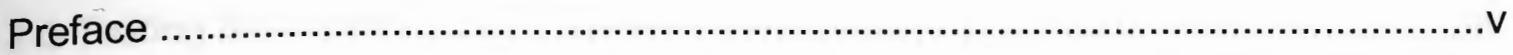

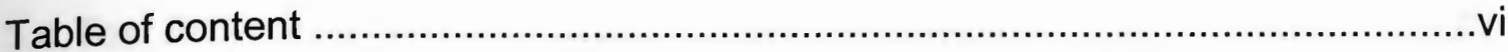

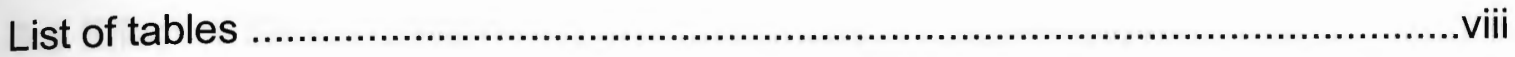

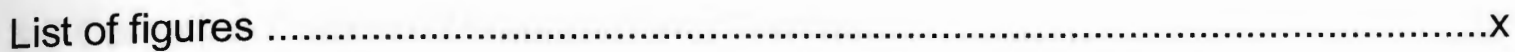

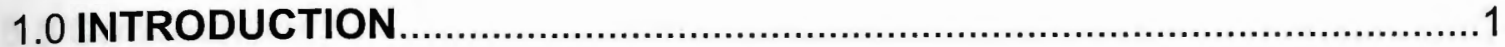

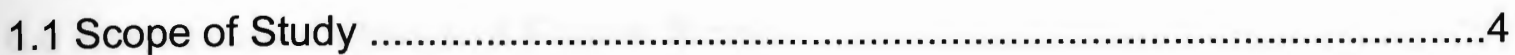

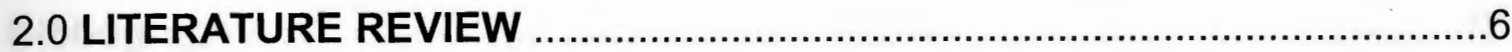

2.1 Corrosion of Reinforcement Steel in Concrete .........................................6

2.2 Corrosion Mechanism of Steel Rebar in Concrete ....................................11

2.3 Techniques of Corrosion Protection for Steel in Concrete ..........................15

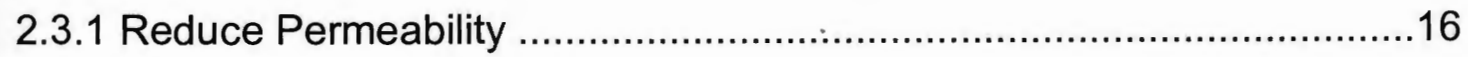

2.3.2 Corrosion Resistance Alloys ..........................................................17

2.3.3 Protective Coatings ................................................................... 18

2.3.4 Corrosion Inhibitors ......................................................................

2.3.5 Use of Surface Coating on the Concrete ........................................20

2.3.6 Cathodic Protection of Steel in Concrete ......................................21

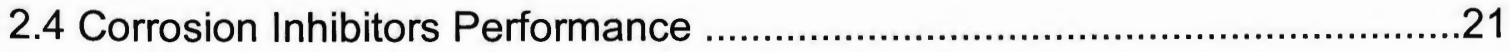




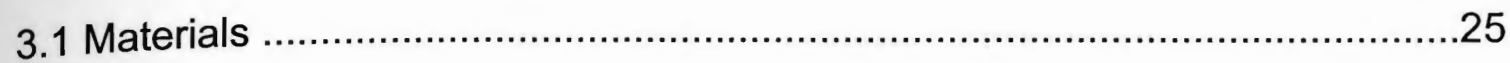

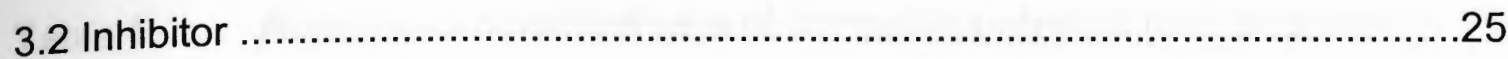

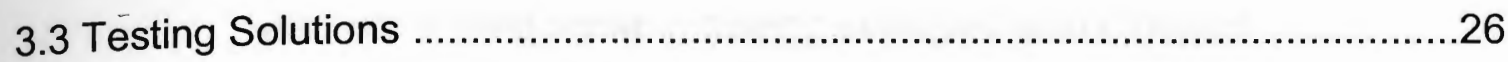

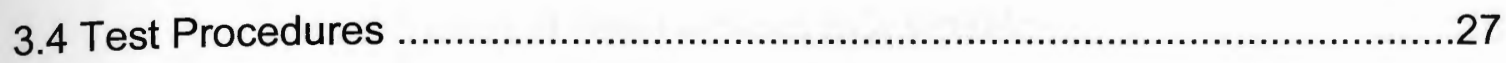

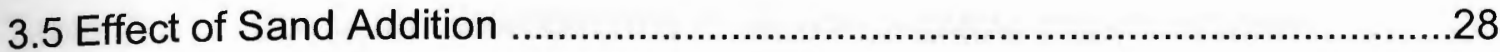

3.6 Corrosion Potential Measurements Testing …......................................29

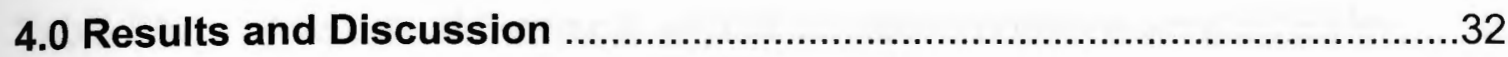

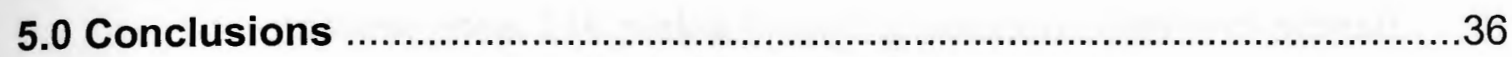

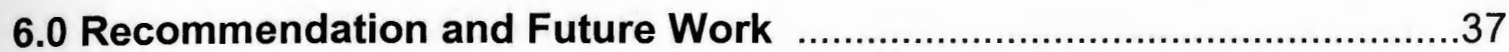

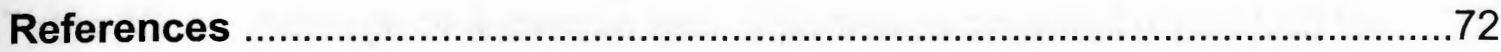

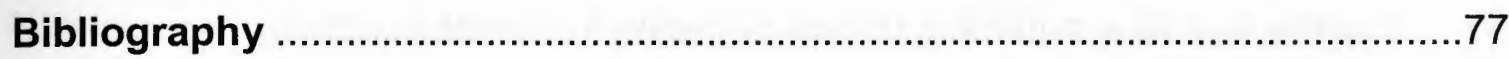




\section{LIST OF TABLES}

Table 1. Average of 3 sample sets of corrosion potential (mV SCE) for end cut 3 " long rebar in testing solutions with different concentration of $\mathrm{NaCl}$ without $\mathrm{DCl}$ inhibitor .38

Table 2. Corrosion potential ( $m V$ SCE) for $U$ shape rebar samples

Exposed to $0.5 \mathrm{~N} \mathrm{NaCl}$ testing solution

Table 3A. Average of 3 sample sets of corrosion potential ( $\mathrm{mV}$ SCE) for stainless steel 316 plates in testing solutions with and without addition of $0.5 \mathrm{~N} \mathrm{NaCl}$

Table 3B. Average of 3 sample sets of corrosion potential (mV SCE) for stainless steel 316 plates in testing solutions with and without addition of $0.5 \mathrm{~N} \mathrm{NaCl}$

Table 3C. Average of 3 sample sets of corrosion potential (mV SCE) for stainless steel 316 plates in testing solutions with and without addition of $0.5 \mathrm{~N} \mathrm{NaCl}$

Table 3D. Average of 3 sample sets of corrosion potential ( $m V$ SCE) for stainless steel 316 plates in testing solutions with and without addition of $0.5 \mathrm{~N} \mathrm{NaCl}$

Table 4A. Average of 3 sample sets of corrosion potential (mV SCE) for stainless steel 316 plates in testing solutions with and without addition of $0.5 \mathrm{~N} \mathrm{NaCl}$ 
Table 4B. Average of 3 sample sets of corrosion potential (mV SCE) for stainless steel 316 plates in testing solutions with and without addition of $0.5 \mathrm{~N} \mathrm{NaCl}$

Table 4C. Average of 3 sample sets of corrosion potential ( $m V$ SCE) for stainless steel 316 plates in testing solutions with and without addition of $0.5 \mathrm{~N} \mathrm{NaCl}$ 46

Table 5A. Average of 3 sample sets of corrosion potential ( $\mathrm{mV} \mathrm{SCE}$ ) for end cut 3 " long rebar in testing solutions with different concentration of $\mathrm{NaCl}$ and $\mathrm{DCl}$ inhibitor

Table 5B. Average of 3 sample sets of corrosion potential (mV SCE) for end cut 3 " long rebar in testing solutions with different concentration of $\mathrm{NaCl}$ and $\mathrm{DCl}$ inhibitor 


\section{LIST OF FIGURES}

Figure 1. Cross section of stainless steel $316 \mathrm{~L}$ rebar clad around conventional steel core.

Figure 2. Glass tube, "O" ring and clamp to be clamped onto the surface of the stainless steel plates sample .50

Figure 3. Example of the glass tubes clamped onto the surface of the stainless steel 316 plates sample with exposed area of $5 \mathrm{~cm}^{2} \ldots \ldots . .51$

Figure 4. Stainless steel rebar with end cut, 3" long ...............................52

Figure 5. Saturated Calomel Reference Electrode (SCE) ........................53

Figure 6. Data average of 3 samples sets of corrosion potential ( $m V$ SCE) verses time for end cut 3" long rebar in different testing solutions .54

Figure 7. Corrosion of stainless steel rebar end cut 3" long exposed to $0.5 \mathrm{~N} \mathrm{NaCl}$ for 16 days without $\mathrm{DCl}$ inhibitor .55

Figure 8. Corrosion of stainless steel rebar end cut 3" long exposed to $0.25 \mathrm{~N} \mathrm{NaCl}$ for 16 days without $\mathrm{DCl}$ inhibitor 55

Figure 9. Corrosion of stainless steel rebar end cut 3" long exposed to $0.5 \mathrm{~N} \mathrm{NaCl} \&$ Simulated Pore Solution for 16 days without $\mathrm{DCl}$ inhibitor 56

Figure 10. Corrosion of stainless steel rebar end cut 3" long exposed to $0.25 \mathrm{~N} \mathrm{NaCl} \&$ Simulated Pore Solution for 16 days without $\mathrm{DCl}$ inhibitor 
Figure 11. Average data of 3 samples sets of corrosion potential (mV SCE) verses time for U shape rebar 3" and 4" Diameter exposed to $0.5 \mathrm{~N} \mathrm{NaCl}$ testing solution

Figure 12. Average data of 3 sample sets of corrosion potential (mV SCE) verses time for stainless steel plates in testing solutions with and without addition of $0.5 \mathrm{~N} \mathrm{NaCl}$ .58

Figure 13. Average data of 3 sample sets of corrosion potential (mV SCE) verses time for stainless steel plates in testing solutions with and without addition of $0.5 \mathrm{~N} \mathrm{NaCl}, 5 \mathrm{gm}$ of sand added 59

Figure 14. Stainless steel rebar end cut 3" long exposed to

$0.25 \mathrm{~N} \mathrm{NaCl} \&$ Simulated Pore Solution with $0.25 \mathrm{~N} \mathrm{DCl}$ Inhibitor for 177 days

Figure 15. Stainless steel rebar end cut 3" long exposed to $0.25 \mathrm{~N} \mathrm{NaCl} \&$ Simulated Pore Solution with $0.25 \mathrm{~N} \mathrm{DCl}$ Inhibitor for 177 days 60

Figure 16. Stainless steel rebar end cut 3" long exposed to $0.25 \mathrm{~N} \mathrm{NaCl}$ with $0.25 \mathrm{~N} \mathrm{DCI}$ Inhibitor for 177 days

Figure 17. Stainless steel rebar end cut 3" long exposed to $0.25 \mathrm{~N} \mathrm{NaCl}$ with $0.25 \mathrm{~N} \mathrm{DCl}$ Inhibitor for 177 days 61

Figure 18. Stainless steel rebar end cut 3" long exposed to $0.5 \mathrm{~N} \mathrm{NaCl} \&$ Simulated Pore Solution with $0.5 \mathrm{~N}$ DCI Inhibitor for 177 days 62 
Figure 19. Stainless steel rebar end cut 3 " long exposed to

$0.5 \mathrm{~N} \mathrm{NaCl} \&$ Simulated Pore Solution with $0.5 \mathrm{~N} \mathrm{DCl}$ Inhibitor

for 177 days

Figure 20. Stainless steel rebar end cut 3" long exposed to

$0.25 \mathrm{~N} \mathrm{NaCl}$ with $0.5 \mathrm{~N} \mathrm{DCl}$ Inhibitor for 177 days

Figure 21. Stainless steel rebar end cut 3" long exposed to

$0.25 \mathrm{~N} \mathrm{NaCl}$ with $0.5 \mathrm{~N} \mathrm{DCl}$ Inhibitor for 177 days

Figure 22. Stainless steel rebar end cut 3" long exposed to $0.25 \mathrm{~N} \mathrm{NaCl} \&$ Simulated Pore Solution with 0.5N DCI Inhibitor

for 177 days.

Figure 23. Stainless steel rebar end cut 3" long exposed to

$0.25 \mathrm{~N} \mathrm{NaCl} \&$ Simulated Pore Solution with $0.5 \mathrm{~N} \mathrm{DCl}$ Inhibitor

for 177 days.

Figure 24. Stainless steel rebar end cut 3" long exposed to $0.5 \mathrm{~N} \mathrm{NaCl}$

with $0.5 \mathrm{~N} \mathrm{DCl}$ Inhibitor for 177 days.

Figure 25. Stainless steel rebar end cut 3" long exposed to

$0.5 \mathrm{~N} \mathrm{NaCl}$ with $0.5 \mathrm{~N} \mathrm{DCl}$ Inhibitor for 177 days.

Figure 26. Stainless steel rebar end cut 3". long exposed to

$0.5 \mathrm{~N} \mathrm{NaCl} \&$ Simulated Pore Solution with $0.25 \mathrm{~N} \mathrm{DCl}$ Inhibitor

for 177 days.

Figure 27. Stainless steel rebar end cut 3" long exposed to

$0.5 \mathrm{~N} \mathrm{NaCl} \&$ Simulated Pore Solution with $0.25 \mathrm{~N} \mathrm{DCl}$ Inhibitor for 177 days. 
Figure 28. Stainless steel rebar end cut 3" long exposed to $0.5 \mathrm{~N} \mathrm{NaCl}$ with $0.25 \mathrm{~N} \mathrm{DCl}$ Inhibitor for 177 days

Figure 29. Stainless steel rebar end cut 3" long exposed to $0.5 \mathrm{~N} \mathrm{NaCl}$ with $0.25 \mathrm{~N} \mathrm{DCl}$ Inhibitor for 177 days

Figure 30. Average data of 3 samples sets of corrosion potential (mV SCE)

verses time for end cut 3" long rebar in testing solutions with different concentration of $\mathrm{NaCl}$ without $\mathrm{DCl}$ inhibitor .68

Figure 31. Preparation of ASTM G109 test for bend stainless steel rebar samples with $2.5^{\prime \prime}, 4.5^{\prime \prime}$ and $5.5^{\prime \prime}$ Diameter 69

Figure 32. Preparation of ASTM G109 test for stainless steel rebar samples .70

Figure 33. Preparation of ASTM G109 test for conventional steel rebar samples 


\section{Chapter 1}

\subsection{Introduction}

Corrosion of the reinforcing steel in concrete structures such as motorway bridges, buildings and marine installations costs billions of dollars per year. A study by CC Technologies and NACE in the USA shows the total direct cost of corrosion was determined to be $\$ 279$ billion per year, which is 3.2 percent of the U.S. gross domestic product. Many of these structures continue to require extensive maintenance or replacement. According to a 1997 report, of the 581,862 bridges in and off the U.S.A. federal-aid system, about 101,518 bridges were rated as structurally deficient, primarily due to corrosion of steel and steel reinforcement. Most of these bridges were not in danger of collapse, but they were likely to be load limit posted so that overweight trucks will be required to take a longer alternative route. Of this total, 200,000 bridges are steel, 235,000 are conventional reinforced concrete, 108,000 bridges are constructed using prestressed concrete, and the balance is made using other materials of construction. The annual direct cost of corrosion for highway bridges is estimated to be $\$ 8.3$ billion, consisting of $\$ 3.8$ billion to replace structurally deficient bridges over the next ten years, $\$ 2.0$ billion for maintenance and cost of capital for concrete bridge decks, $\$ 2.0$ billion for maintenance and cost of capital for concrete substructures, and $\$ 0.5$ billion for maintenance painting of steel bridges. ${ }^{1}$ The primary cause for the deterioration of concrete bridges is the corrosion of reinforcing steel dues to the presence of soluble chloride which is usually 
introduced to concrete structure in the ways of deicing chemical, marine exposure, bleaching operations, spillage and contaminated aggregate. ${ }^{2}$ This has placed tremendous financial burden on many states and local transportation agencies in their attempts to halt ongoing reinforcing steel corrosion in the existing structures that are still functional and to replace those structures that have already deteriorated to the point that it does not make any economic sense to keep on maintaining them. In addition, badly deteriorated bridges have considerable adverse effects on the nation's economic output and also place the safety of motorists at risk.

The major cause of concrete structures failure is caused by the corrosion of the reinforcing steel in the concrete that is induced by the intrusion of even a small amount of chloride from the deicing salts into the concrete which are extremely corrosive due to the disruptive effects of its chloride ions on protective films on metals. Another cause is the general breakdown of passivity by neutralization of the concrete, predominantly by reaction with atmospheric carbon dioxide. Concrete is an ideal environment for steel but the increased use of deicing salts and the increased concentration of carbon dioxide in modern environments principally due to industrial pollution, has resulted in corrosion of the rebar becoming the primary cause of failure of this material. The scale of this problem has reached alarming proportions in various parts of the world. Even though the cost of maintaining concrete structures is becoming prohibitively expensive mainly due to the effects of deicing salts, the benefits provided by adding these salts on icy roads are too great for their use to see any decrease in 
the future. It is difficult to estimate the cost of these corrosion-related damages to conventionally reinforced and pre-stressed concrete bridge components in the nation. Corrosion of the reinforcing steel is a significant contributor and has becomes a matter of major concern. Therefore, Construction engineers need better techniques for assessing when maintenance is necessary and possible or when replacement is the only viable option.

When a concrete structure is exposed to deicing salts, salt splashes, and salt spray, or seawater, chloride ions from these will slowly penetrate into the concrete. The chloride ions will eventually reach the steel and then accumulate to beyond a certain concentration level, at which the protective film is destroyed and the steel begins to corrode when oxygen and moisture are present in the steelconcrete interface. ${ }^{3}$ As the steel rebar corrodes, it expands causing the surrounding concrete to crack. Cracking allows more chlorides laced water to enter which causes further corrosion and further cracking and spalling. Bleeding of the rust products from the cracks in the concrete can be observed then. Spalling is caused by the volume increase when rust forms on the steel due to the oxidation of iron. This increase in volume induces tensile stresses in the concrete and initiates cracks. Corrosion induced cracks and spalling of the concrete may happen within a few years of service time. ${ }^{4}$ These cracks in turn provide further access to corrosive environmental agents that accelerate degradation of the structure ${ }^{3}$. 
Several methods may be used to stop or retard the corrosion of steel in reinforced concrete. They can be classified as either mechanical methods such as protective coating/cladding layer or electrochemical methods such as cathodic protection and corrosion inhibitors. Isolate the reinforced steel surface from the medium by coating or cladding the rebar with a good corrosion resistance material such as epoxy coating that would protect the steel from corrosion. Another coating or cladding way is to use steel bars with metallic coatings such as zinc, or stainless steel cladding rebar. The coating must be impervious to chloride, moisture, and oxygen. Another requisite property is that the coating be durable so that it cannot be damaged during transportation to the construction site. It must also be economical; if the material costs so much that it is more expensive than replacing the steel tendons periodically, then it is not worth it to use that material.

\subsection{Scope of study}

Conventional carbon steels are prone to all types of corrosion in severe corrosion environment, where as stainless steels are to be used with due care to cracking, pitting and crevice corrosion to some extent. Austenitic stainless steels, chrome nickel alloy with molybdenum, have been developed to over come the short comings of stainless steels such as embrittlement, intergranular corrosion and welding problem. Extra low carbon level assures resistance to intergranular corrosion. However, the higher cost of stainless steel 
is considered to be a barrier to its wider application. As a result, a combination of stainless steel and carbon steel, stainless steel clad rebar, was developed to overcome the cost effectiveness with higher yield strength than solid stainless steel rebar. The cost is about 20 to $25 \%$ of the solid stainless steel rebar ${ }^{5}$. In this study, the primary focus is the field evaluation of the stainless clad steel rebar as protective covering of concrete structure to control corrosion. The objectives of this study are to develop a laboratory test methods to evaluate corrosion inhibitors admixtures to be used in the repair of stainless clad steel reinforced concrete structures. Exposure and laboratory test have been conducted on stainless steel 316 in various testing solutions to understand the initiation conditions of crevice corrosion in concrete environment. 


\section{Chapter 2}

\section{Literature Review}

\subsection{Corrosion of Reinforcement Steel in Concrete}

Concrete is a hardened mixture of cement, aggregates and water. The Hydration which is the reaction between water and cement takes place slowly as a result of important properties such as strength and permeability change continuously. If there is no inter action with the environment they will improve with time, the concrete will be stronger and denser and therefore protect the reinforcement structure. The major prevention factor when it comes to concrete is the $\mathrm{pH}$ of the pore solution in the concrete at the steel surface. The composition of the pore solution depends on the hydration of the cement and water which is mainly depends on the cement composition.

The main three cement compositions are: first cements mainly composed of Portland cement clinker, second cements composed of Portland cement clinker and the latent hydraulic blast-furnace slag, and third cements composed of Portland cement and pozzolanic material fly ash, silica fume, trass and pozzolan. The hydration is a reaction of four clinker materials: Tricalcium Silicate $\left(3 \mathrm{CaO} \cdot \mathrm{SiO}_{2}\right)$, Dicalcium Silicate $\left(2 \mathrm{CaO} \cdot \mathrm{SiO}{ }_{2}\right)$, Tricalcium Aluminate $\left(3 \mathrm{CaO} \cdot \mathrm{Al}_{2} \mathrm{O}_{3}\right)$ and Tetracalcium Ferite $\left(4 \mathrm{CaO} \cdot \mathrm{Al}_{2} \mathrm{O}_{3} \cdot \mathrm{Fe}_{2} \mathrm{O}_{3}\right)$. When these materials react with water they give unsolvable precipitates of calcium silicate hydrates and calcium 
aluminate hydrates which can be called the cement gel. ${ }^{6}$ The calcium silicates and dicalcium silicates can produce a free lime $\left(\mathrm{Ca}(\mathrm{OH})_{2}\right)$ which is not very soluble. The free lime will react with the sodium and potassium salts which can be found the minor quantities of the cement clinker giving rise to the formation of very soluble potassium and sodium hydroxide. During the first few hours of the hydration of the cement the $\mathrm{pH}$ originated partly from production of the super saturated calcium hydroxide partly from sodium and potassium hydroxide in the pore liquid. The potassium hydroxide and sodium in the solution will determine the $\mathrm{pH}$ value. The amount of the calcium hydroxide will be determined by the amount of the $\mathrm{C}_{3} \mathrm{~S}$ and $\mathrm{C}_{2} \mathrm{~S}$ in the Portland cement clinker. ${ }^{7}$

The amount of buffering substance $\left(\mathrm{Ca}(\mathrm{OH})_{2}\right)$ for the penetrating $\mathrm{CO}_{2}$ decreases with the amount of slag or Pozzolanic material. From this point of view blast-furnace cement concrete and concretes with pozzolanic materials should give less protection with time. However, the additional reaction within blended cements leads to less or much less permeable concrete. The pozzolanic reaction leads to filling of the pores. The decrease in buffering capacity or even decrease in $\mathrm{pH}$ is therefore counteracted by the decrease in permeability. Additionally, the pozzolanic reaction leads to an increase of the electrical resistivity and decrease of mobility of aggressive ions and therefore decreasing the corrosion. ${ }^{8}$ 
The corrosion of steel in concrete structure is mainly due to aggressive salts. Concrete usually provides steel with high degree of protection against corrosion. Concrete is alkaline which means that it contains microscopic pores with high concentrations of soluble calcium, sodium and potassium oxides. These oxides form hydroxides, which are very alkaline, when water added. The chemical reaction that takes place creates a high alkaline condition $(\mathrm{pH} 12-13){ }^{4}$ This alkaline condition leads to a passive layer forming on the steel surface. A passive layer is a dense protective film which prevents further corrosion of the steel if fully established and maintained. The layer formed on the steel in concrete is part metals oxides / hydroxides and parts minerals from the cement. The passive layer will maintain and repair itself as long as the passivating alkaline environment can be maintained. However, the passivating environment is not always maintained. Two processes can break down the passivating environment in concrete. One is carbonation and the other is chloride attack.

Most of the researches are related to the corrosion of steel in concrete structures due to the deicing salts used in winter and nearby the coastal areas or to the early corrosion of structures due to incorporation of calcium chloride into the concrete mix to aid early strength development. The concrete may in itself deteriorate as a result of many factors, for example sulphate attack, alkali aggregate reaction or physical deterioration due to the action of sea water or soft water. The damage to concrete would then lead to corrosion of the steel. However, steel can corrode within few years as the chloride frints moves into 
even highly strength well compact concretes showing very little sign of carbonation. ${ }^{6}$ The corrosion protection afforded by concrete to encapsulated steel depends on complex relationships between the chemical and physical characteristics of the concrete. Chemically, the highly alkaline hydration products of cement with $\mathrm{PH} 12.6$ presents in the concrete pore moisture ensures complete electrochemical passivity of the steel due to the formation of the protective film on the steel. As long as this protective film is maintained by a sufficiently high $\mathrm{PH}$ and is not disrupted by aggressive substances, complete protection of the steel can be expected. The physical characteristics of the concrete, as well as its uniformity, will determine the concrete's ability to retain a high $\mathrm{PH}$ and exclude aggressive substance from the steel. Reduction in $\mathrm{PH}$ can occur either through carbonation of the concrete or leaching out calcium hydroxide. The presence of chloride in the concrete results in the breakdown of the protective film on the steel. ${ }^{9}$

Most corrosion phenomena is because of electrochemical nature. It implies two or more electrode reactions: the oxidation of a metal, anodic partial reaction, and the reduction of an oxidizing agent, cathodic partial reaction. It is a spontaneous process of returning metals to their natural state by oxidation-reduction reaction. Corrosion of metals results in a loss of both structural integrity and attractive appearance. ${ }^{10}$ The general equilibrium reaction for a metal electrode is:

$$
\mathrm{M} \leftrightarrow \mathrm{Mz}^{+}+\mathrm{ze}^{-}
$$


Where $\mathrm{M}$ represents a metal atom, $\mathrm{Mz}^{+}$is the metal ion, $\mathrm{z}$ is the valence(s) and $\mathrm{e}^{-}$represents an electron.

The corrosion of base metals in aqueous environment proceeds by an electrochemical mechanism. Once the passive layer breaks down, areas of rust will start to appear on the steel surface. The chemical reaction is the same in both cases, carbonation and chloride attack. When steel corrodes in concrete it dissolves in the pore water and gives electrons. ${ }^{11}$

The anodic reaction can be expressed by:

$$
\mathrm{Fe} \rightarrow \mathrm{Fe}^{2+}+2 \mathrm{e}^{-}
$$

The two electrons created in the anodic reaction must be consumed else where on the steel surface. Therefore, it's not possible for large amount of electrical charges to build up at one place on the bar

Another chemical reaction must take place that will consume the electrons. This reaction consumes water and oxygen. Dissolved Oxygen in pore water that has diffused to steel surface is reduced by electrons supplied by anode reaction to form hydroxyl ions which can be expressed by the cathodic reaction:

$$
2 \mathrm{e}^{-}+\mathrm{H}_{2} \mathrm{O}+0.5 \mathrm{O}_{2} \rightarrow 2 \mathrm{OH}^{-}
$$


The hydroxyl ions increase the local alkalinity and will strengthen the passive layer and minimizing effects of carbonation and chloride ions at the cathode. Water and oxygen are needed at the cathode for corrosion to occur. If chloride ions are present on carbonated concrete, steel rebar will corrode if the oxide layer is damaged and oxygen and water are present. ${ }^{12}$ This takes place because $\mathrm{Fe}^{2+}$ in the form of chloride complex migrate away exposing the steel to corrosion. This chloride complex is further oxidation to different $\mathrm{Fe}^{2+}$ as seen in the following reaction:

$$
\begin{gathered}
\mathrm{Fe}^{2+}+\mathrm{Cl}^{-}+\mathrm{OH}^{-} \rightarrow \quad \\
(\mathrm{FeCl})^{+} \mathrm{OH}^{-} \text {(soluble chloride complex) } \\
\downarrow \mathrm{H}_{2} \mathrm{O}, \mathrm{O}_{2} \\
\left(\mathrm{Fe}(\mathrm{OH})_{3}, \mathrm{Fe}_{2} \mathrm{O}_{3}, \mathrm{Fe}_{3} \mathrm{O}_{4}\right) \cdot \mathrm{n}\left(\mathrm{H}_{2} \mathrm{O}\right)
\end{gathered}
$$

\subsection{Corrosion Mechanism of Steel Rebar in Concrete}

The most prevalent deterioration mechanisms of reinforcement corrosion involve chloride ions, as found in salts, or the reduction of $\mathrm{pH}$ in concrete as a result of carbonation of the cement binder. Chloride ions may be contained in the original constituents of concrete, from mixing water, aggregate or admixtures, or they may be absorbed from the environment into the concrete matrix during the life of the structure. In current practice, efforts are generally made to minimize the amount of chloride in concrete constituents, so the majority of 
chloride that results in deterioration is derived from the environment.

Environmental sources of chloride include seawater, ground water, or salts used in deicing operations during winter months. Over time, chloride ions or compounds penetrate through the cover concrete to the depth of the reinforcement through a process called diffusion. ${ }^{13}$

A simple model of the chemical reactions associated with corrosion deterioration of steel within concrete follows. Oxidization of iron $\left(\mathrm{Fe}^{++}\right)$molecules naturally occurs immediately after the bar is manufactured and exposed to the atmosphere, and will continue so long as sufficient oxygen and moisture are available to react with the steel. Upon exposure to the high $\mathrm{pH}$ environment of concrete, a passive layer of oxidation product forms on the encapsulated steel surface. This passivation process is actually a form of corrosion. However, in the moist, high $\mathrm{pH}$ environment of concrete, the reaction occurs at an everdecreasing rate. In the absence of aggressive ions, oxidation nearly ceases after a sufficient passive layer has formed. ${ }^{14}$ The passive layer normally protects the reinforcement from spontaneous corrosion in a moist, oxygen-rich environment such as concrete. However, chloride ions $\left(\mathrm{Cl}^{-}\right)$that diffuse to the steel surface can disrupt the passive layer and induce corrosion. Generally, metal atoms pass into solution as positively charged ions at the anodic site and liberated electrons flow through the metal to cathodic sites where dissolved oxygen is available to consume them. For example, chloride ions react with iron compounds in the passive layer to create an iron-chloride complex $\left(\mathrm{FeCl}_{2}\right)$, which subsequently 
reacts with hydroxide $\left(\mathrm{OH}^{-}\right)$from the surrounding concrete to form hydrated iron oxide compounds. This is commonly known as the anodic reaction.

Simultaneously, at an alternate location on the steel surface, oxygen $\left(\mathrm{O}_{2}\right)$ reacts with water $\left(\mathrm{H}_{2} \mathrm{O}\right)$ and electrons released by the anodic reaction to form hydroxide. This is referred to as the cathodic reaction. Together, the anodic reaction and the cathodic reaction form a corrosion cell.

Many corrosion cells may exist along the same steel member and within a concrete member simultaneously. Localized corrosion, or micro-cell corrosion, involves anode and cathode reactions occurring adjacent to one another on the same surface. Macro-cell corrosion cells involve anode and cathode reactions occurring at distant locations on the same element or on different bars, or metal elements that are electrically continuous.

Collectively, the anodic and cathodic reactions must be balanced.

Therefore, in order for the reactions to occur at the same rate, a balance of the following elements is required:

Iron $\left(\mathrm{Fe}^{++}\right) \quad$ - provided by the reinforcing steel

Chloride $\left(\mathrm{Cl}^{-}\right)$- from the environment or concrete constituents

Oxygen $\left(\mathrm{O}_{2}\right)$ - from the environment

Water $\left(\mathrm{H}_{2} \mathrm{O}\right)$ - from concrete and environment 
A crucial characteristic of the corrosion mechanism is that the hydrated iron oxide compounds occupy greater volume than the original reactants, the exact proportion depending upon the composition of the compounds and conditions of the confining environment. As the volume of accumulated reaction products increases, pressure is generated within the concrete, which may ultimately exceed the tensile capacity of the concrete and result in cracking, delamination and spalling. ${ }^{15}$

Once chloride has reached the reinforcing steel in concentrations above the threshold limit (typically 0.6 to 1.2 kilograms of chloride ion per cubic meter of concrete for uninhibited systems ${ }^{16}$, the deterioration of the passive layer initiates, and the corrosion process begins. Research has shown that the arrival of sufficient chloride to initiate sustained corrosion is marked shortly thereafter by a sharp increase in the magnitude of electrical potential of the reinforcing steel, as measured against a standard reference probe, such as a copper-copper sulfate electrode (CSE) or standard calomel electrode (SCE). Although the magnitude of the electrical potential does not directly relate the rate of corrosion, it may provide a reasonable indication of the probability that corrosion is occurring. ${ }^{17}$

The presence of the diffusing reactants, including chloride, oxygen and moisture, are fundamental to the rate at which corrosion progresses. Environmental factors such as temperature and $\mathrm{pH}$ of the concrete will also affect 
the rate of corrosion. Reactions in various zones of a concrete member or structure will likely occur at different rates and times, depending upon variations in environmental exposure and electrochemical interaction between the zones. ${ }^{18}$

It was stated previously that, as the corrosion process continues, the volume of corrosion product increases until the tensile strength of the concrete is exceeded and cracking occurs. Such cracking will emanate from the reinforcement to the nearest surface, and a direct path is created for further ingress of chloride, oxygen and water to the steel surface. As further amounts of corrosion products accumulate, the crack will evolve into a delamination or spall, resulting in the effective or actual loss of concrete cover, and leaving the steel directly exposed to the source of reactants, the environment.

\subsection{Techniques of Corrosion Protection for Steel in Concrete}

Several techniques exist for reducing the likelihood of corrosion of the reinforcing bars in concrete structures such as, protective coating of the steel, cathodic protection, or the use of alternatives such as alloy steels and nonmetallic materials. However, uncertainty regarding the interaction of the constituents of the concrete, the effects of aggressive chemicals in the environment and the susceptibility to attack of the reinforcement make the choice of protection difficult. The repair of concrete structures that have been damaged by corrosion of embedded reinforcement is both costly and disruptive process. 
The ideal solution is to provide a corrosion protection system at the time of construction that effectively prevents corrosion from starting. No system is Ideal and a combination of methods is required. Several different methods to prevent or remedy corrosion induced by chloride intrusion may used, some of these methods are:

\subsubsection{Reduce permeability}

One of the most common ways to reduce corrosion is to increase the cover over rebar. Adding just an extra inch or two of concrete cover could reduce the ability of corrosive agents to penetrate the concrete and corrode the reinforcing steel which can extend the life of a structure. It is well known now that the most common cause of corrosion staining on concrete decks is poor placement of the rebars. Another way to prevent chloride intrusion is to reduce the permeability of concrete. Since chlorides are usually introduced in solution, reduction of water permeability will reduce chloride ion permeability. Concrete mixtures with a low water/cement ratio will produce concrete with lower permeability. Reducing the water-cement ratio seems like a simple method for reducing permeability, but in order to produce workable concrete, water-reducing admixtures are necessary. These admixtures increase the workability of concrete without additional water. Water-reducing admixtures can decrease water content for a given slump by $5-10 \%$, while superplasticizers may reduce water content 
by $15-30 \%$. Addition of pozzolans may also decrease the permeability of concrete. Silica fume, fly ash and ground granulated blast furnace slag in concrete will significantly reduce the water permeability of concrete. These pozzolans react with the calcium hydroxide produced by the reaction of water and cement to produce additional C-S-H, which occupies more of the pore spaces. ${ }^{19}$ This aspect is important at the interface of the aggregates with the cement paste. Normally, the aggregate-paste interface enjoys the highest permeability. This area is referred to as the transition zone, where a porosity gradient exists. Permeability in the transition zone may increase by a factor of ten. Silica fume addition creates direct contact between aggregate and paste reducing or eliminating the effect of the transition zone on permeability. Strong concrete with a low water-to-cement ratio will have a low permeability and be less susceptible to corrosion.

\subsubsection{Corrosion resistance alloys}

Alternative material for reinforcing steel has been considered and tested. However, many of these materials are generally disqualified based on cost or safety requirements. New candidate rebars being considered are 2205 and 2101 duplex steels, 316LN stainless steel, 316L stainless steel clad and MMFX-2 steel rebar. Stainless steels have proved to be useful as a reinforcing medium where conditions are particularly severe and their cost justify. Solid stainless steel bar does not have the same strength characteristics of a black bar. Stainless steel 
clad rebar has introduced to the market with an excellent corrosion properties in salt solution. Therefore, the option of using stainless steel rebars is attractive now that this new type can be manufactured in commercial quantities at reasonable prices. The stainless cladding is evenly deposited along the surface and metallurgically bonded to the inner carbon steel core. However, the main reason for the making of clad steels is the potential they offer for cost saving, since a portion of the expensive component is replaced by carbon steel. At present, the price ratio of SAE 316 stainless steel to BS $436043 A$ is about 5:1. ${ }^{20}$ The ratio depends largely on the nickel price, which can fluctuate substantially. The composites combine good strength with good corrosion resistance, formability, and weldability. They are used where the design specifies for greater strength and a greater thickness than that required for protection against corrosion. However, this type of stainless steel is susceptible to localized crevice corrosion initiated by chloride ions. Other structural materials, including fiber polymer composites are generally considered undesirable for use as concrete reinforcement since they do not posses the yield characteristic of steel.

\subsubsection{Protective Coatings}

The protection of galvanized reinforcing bars provided by the zinc can function in two ways. Firstly the corrosion rate of the zinc is lower than of the steel, thus once corrosion is initiated; the zinc would last longer than steel would. Secondly, zinc would provide sacrificial protection to the steel. However, this 
treatment has shown mixed results in concrete and may inadequate for desired service life performance in many environments. Another method of steel surface is epoxy coated reinforcing bar. The layer of epoxy prevents water and oxygen from coming in contact with the steel. When using epoxy-coated rebar, extra care must be taken in laying and tying bars. If cracks or holes occur, exposing the steel, the steel will corrode at higher than normal rate. The protection provided by epoxy coating is based on several factors, notably chemical resistance, physical barrier characteristic and their poor electric conductivity. The poor electric conductivity reduces the formation of macro cells. Those reinforcing bars require special handling. If the coating is damaged, it must be repaired before the concrete is placed.

\subsubsection{Corrosion Inhibitors}

Many of these chemicals have been suggested to be effective while others have produced conflicting results. In particular, chromates, nitrites and benzoated have been used for this purpose. They are intended to slow the corrosion process of the steel rebar in concrete without adversely affecting other properties and are typically included as an admixed in the concrete. ${ }^{21}$ Calcium nitrite has probably had the longest track record as a corrosion inhibitor for concrete structures. When added to concrete in sufficient quantity as determined by the anticipated chloride iron contents of the concrete over the design life of the structure, it will provide corrosion resistance to steel within concrete mixture. It 
must be added in sufficient quantity to the entire concrete mix in order to control corrosion at the surface of the reinforcing steel. Therefore, it's important to calculate the chloride exposure for the life of the structure since the correct addition rate is critical for ensuring adequate performance. Furthermore, after exposure to chlorides, calcium nitrite will be consumed and its long term effectiveness is still unknown. ${ }^{22}$ Calcium nitrite does not have a great effect on concrete resistivity and therefore it should be combined with another protection method.

\subsubsection{Use of Surface Coating on the Concrete}

The use of the surface coating for concrete members, including polymers membranes, penetrating sealers and modified cementitious or acrylic coating has often been used to supplement existing of aggressive environment. The application of impermeable surface coating to concrete should reduce corrosion of the reinforcing steel. This can be achieved by reducing the concrete's permeability chloride and reduce oxygen penetration which will slow down the main cathodic reaction. A properly selected and applied coating may reduce the rate of the reaction but by no means eliminates the occurrence of corrosion. 


\subsubsection{Cathodic Protection of Steel in Concrete}

Cathodic protection is widely used for buried pipelines, marine structures, and bridges structures. Cathodic protection based on that corrosion of any metal is a result of an electric current flowing from one part of a metal to the other. Cathodic protection process uses the application of direct current to the rebar using an induced anode material (zinc or magnesium metal) in sufficient quantity to reverse or counteract the natural corrosion current. The benefit of cathodic protection can be shown in its ability to reduce chloride ion migration towards the reinforcing steel. The chloride ion is negative and can be repelled by the negatively charged cathode reinforcing steel. This technique has been particularly successful for rehabilitating existing structures subject to severe corrosion. ${ }^{23}$ The disadvantages of using cathodic protection, as a means of preventing corrosion, are that it is costly and requires constant monitoring.

\subsection{Corrosion Inhibitors Performance}

The focus of this study is to assess the effectiveness of corrosion inhibiting admixtures. Generally, inhibitors admixtures are classified as anodic (Passive system), cathodic (Active system) or mixed (passive-active) inhibitors. This convention reflects the relative location of inhibitor action within the electrochemical cell: at the anode, cathode or both. Anodic inhibitors repress the reaction at the anode sites by their ability to accept electrons. This type of 
inhibitor reacts with the steel to from a protective film. Anodic inhibitors effectiveness is directly dependent upon their concentration relative to chloride. ${ }^{24}$ If the amount of the chloride is too high for the dosage of the corrosion inhibitor, then all of the anodic sites are not eliminated and corrosion continues at a rate greater or equal to that of untreated concrete. Calcium nitrite is a popular anodic inhibitor. Cathodic inhibitors indirectly slow the rate of the reaction often by precipitation at the cathodic sites of an electrochemical cell, or by limiting the availability of oxygen for the cathodic reaction to occur. They form a barrier around the cathodic site to reduce chloride ingress. This type tends to be less efficient than anodic inhibitors. Silica fume is an example of a cathodic inhibitor. Mixed inhibitors perform by both methods.

In addition to specific inhibition at the anodic or cathodic sites on the reinforcing steel, some inhibiting admixtures are believed to reduce the rate of chloride diffusion through the concrete. This added benefit is believed to be the result of alterations in the permeability of the material through interaction between the admixture and the cement paste constituents. ${ }^{25}$

Since the deleterious effects of chloride were identified, much has been done in design and construction practice to limit the amount of chloride present in original construction materials. Therefore, the primary source of chloride in structures today is surrounding environment, such as sea water and salt used in deicing operation, which is direct result of the national bare roads maintenance 
policy in effect since 1960's. ${ }^{25,26}$ Alternative deicing substances have been also investigated, but generally they are too difficult to obtain and cost prohibitive for common use. ${ }^{27}$ Slowing the intrusion through the concrete of aggressive species, such as chloride, is another potential benefit of concrete admixtures. Admixtures that slow this ingress of chloride into concrete generally do so by two methods. Some function by clogging the internal pore solution of the concrete, to deter movement of foreign substances by absorption or diffusion. Reduction in pore size, bridging of pore with interpenetrating film, and lining of pores with compounds imparting hydrophobic properties were cited as potential methods for limiting chloride ingress. Other admixtures method function by scavenging in which aggressive species or oxygen in pore solution are chemically combined or absorbed, rendering them inert in the concrete environment. ${ }^{28}$ Admixtures used specifically to deter chloride ingress or scavenge corrosion reactions have met with little to moderate success and generally the effects are proportion dependent and recede over time. Some admixtures that meet the ISO definition of corrosion inhibitor may also impart one or more of these other benefits in concrete, although it's not their primary function. Active corrosion inhibitors may increase the concentration of chloride necessary to induce corrosion. Many of these form a film or coating surface of the steel, and may react with incoming chloride ions to prevent interaction between chloride ions and the passivated layer of oxidized ions which naturally protect the steel in high $\mathrm{PH}$ concrete environment. ${ }^{29}$ 
Many studies have been performed under both laboratory and field conditions to assess the methods of corrosion deterioration and attempt to predict the time necessary for corrosion to occur and sufficient damage to accumulate to render the structurally or functionally deficient. Several types of test specimens have evolved to simulate the reinforced concrete environment and provide testing for chloride induced corrosion behavior and prevention. 


\section{Chapter 3}

\section{EXPERIMENTAL METHODS}

\subsection{Materials}

The materials used in this research were stainless steel $316 \mathrm{~L}$ clad rebar and stainless steel 316L plates. The composition of this type of stainless steel is $16-18 \%$ chromium, $10-14 \%$ nickel, $0.03 \%$ carbon, $2.0-3.0 \%$ molybdenum, $2.0 \%$ manganese $1.0 \%$ silicon, $0.045 \%$ phosphate and $0.03 \%$ sulfur. The low carbon grade is to reduce the sensitization and assures resistance to intergranular corrosion and avoiding any weld decay. The \# 5 clad stainless steel rebar tested consists of $316 \mathrm{~L}$ stainless steel cladding with a thickness of 1-2 mm over carbon steel core and a total diameter of $16 \mathrm{~mm}$ ( $5 / 8 \mathrm{inch})$ as shown in figure 1 . The dimensions of the $316 \mathrm{~L}$ stainless steel plates were $38.1 \times 38.1 \mathrm{~mm}(1.5 \times 1.5$ inch) with a thickness of $1.6 \mathrm{~mm}$.

\subsection{Inhibitor}

The corrosion inhibiting concrete system to be evaluated in this study is $\mathrm{DCl}$ corrosion inhibitor. $\mathrm{DCl}$ inhibitor is a non-organic inhibitor and a calcium nitrite based system. According to the manufacturers, W. R. Grace Productions, $\mathrm{DCl}$ contains about $30 \%$ calcium nitrite and $70 \%$ water. 


\subsection{Testing Solutions}

Concrete is a porous material containing several classes of pores in the cement paste. The internal pore system retains a significant amount of pore fluid called concrete pore water. Chemistry of the pore water is important for the understanding of migration processes in cement paste and trace elements mobility, including chloride in connection with corrosion of reinforcing steel in concrete. The composition of the concrete pore water solution can be determined by expressing the pore solution from concrete cores using a special high pressure device. It was found that potassium and sodium hydroxide are the primary components of the pore solution. ${ }^{30}$ One of the simulated concrete solutions that thought to approximate the actual pore solution in concrete is simulated pore solution (SPS). The SPS chosen for this study was determined to be the most suitable solution to simulate the concrete environment. Sodium chloride $(\mathrm{NaCl})$ was added to the SPS in various quantities to produce the corrosive environment for tested specimens. The $\mathrm{DCl}$ corrosion inhibitor was added to the Simulated pore solution to evaluate its protective properties against corrosion due to chloride ions present in the solutions. The simulated pore solution is produced by combining sodium hydroxide, potassium hydroxide, calcium hydroxide, and deionized water. The approximate simulated pore solution composition is as the following: $0.03 \mathrm{M}$ potassium hydroxide $(\mathrm{KOH})$, $0.01 \mathrm{M}$ sodium hydroxide $(\mathrm{NaOH})$ and $0.001 \mathrm{M}$ Calcium hydroxide $\mathrm{Ca}(\mathrm{OH})_{2}$. The other solutions is calcium hydroxide which contains $1.85 \mathrm{~g} \mathrm{Ca}(\mathrm{OH})_{2}$ per liter of 
deionized water. Plain water will be used as one electrolyte while $0.25 \mathrm{~N}$ and $0.5 \mathrm{~N} \mathrm{Nacl}$ additions will be made to simulate corrosion conditions.

\subsection{Test procedures}

Plates of stainless steel $316 \mathrm{~L}$ was exposed to saturated calcium hydroxide $\mathrm{Ca}(\mathrm{OH})_{2}$, simulated pore solution (SPS), $\mathrm{NaCl} \& \mathrm{SPS}$, and $\mathrm{NaCl} \& \mathrm{Ca}(\mathrm{OH})_{2}$. Glass tubes were clamped onto the surface of the plates sample as shown in figure 2,3 . The exposed areas of the samples were $5 \mathrm{~cm}^{2}$. Five grams of sand was added to another set to create the interfaces necessary for crevice corrosion. The potential of the system was compared to a reference electrode SCE and was monitored to evaluate corrosion performance. These samples were monitored as crevice corrosion could incubate. Triple samples were run for each condition.

Stainless steel Clad rebar was cut into 3 inch $(76.2 \mathrm{~mm})$ long as shown in figure 4. The samples were suspended into $0.5 \mathrm{~N} \mathrm{NaCl} \& \mathrm{SPS}, 0.25 \mathrm{~N} \mathrm{NaCl} \&$ SPS, $0.5 \mathrm{~N} \mathrm{NaCl}$, and $0.25 \mathrm{~N} \mathrm{NaCl}$ solutions. $\mathrm{DCl}$ commercial corrosion inhibitor was added to another set with different concentration to evaluate its performance on the end cut rebar. The effect of bending of the clad rebar was investigated by suspending 4 and 5 inches diameter rebar into $0.5 \mathrm{~N} \mathrm{NaCl}$ and $0.25 \mathrm{~N} \mathrm{NaCl}$ solutions. Potential change was used to determine the onset of corrosion. 
Corrosion potential was measured for all samples with a SCE reference electrode as in figure 5.

\subsection{Effect of Sand Addition}

The effect of the sand on accelerating or inhibiting the crevice or pitting corrosion was investigated. The characteristics of the sand are determined by the physical and mineralogical composition of the parent materials. The classification of the sand is based on its physical and chemical properties. Chemical analyses of sand for corrosion purposes are usually limited to determination of the elements that are soluble in water like salts. The base forming elements are usually sodium, potassium, calcium and magnesium. The acid forming elements are carbonate, bicarbonate, chloride, nitrate, and sulfate. The development of acidity in sand is a result of the natural process of weathering under humid conditions. Bacteria may affect the chemical properties of the sand. Certain types of bacteria are capable of fixing atmospheric nitrogen and converting nitrogenous material in the sand to a form useful to plant life.

Other bacteria convert sulfur and sulfides to sulfates and still others accomplish the reverse reaction 


\subsection{Corrosion Potential Measurements Testing}

Corrosion potential measurement was used in this study. As such, the corrosion potential is a basic indicator of the thermodynamic corrosion status. It can be used in conjunction with Pourbaix diagrams. Unfortunately, on its own, the potential value does not provide information on the rate of corrosion (kinetics). Corrosion potentials can provide a useful indication of active or passive behavior in certain systems. The corrosion potential is the electrical voltage difference between an electrode and a reference electrode. We cannot measure the absolute potential of an electrode; therefore, the electrode potential must always be referred to an arbitrary zero point, defined by the potential of the reference electrode. Consequently, it is very important always to note the type of reference electrode used in the measurement of the electrode potential. Calomel electrode is a commonly used reference electrode and very similar to the silver/silver-chloride electrode both in construction and in theory of operation.

The silver metal is replaced by mercury (electrical connection is made by an inert metal wire), the salt is mercury chloride, and the solution is saturated potassium chloride, abbreviated as SCE for saturated calomel electrode.

The electrical potential of an electrode measured against the reference electrode when there is no current flowing through the electrode. In other words, the electromotive force of an electrochemical cell consists of the electrode and a reference electrode. The concept of equilibrium potential is probably easiest to 
demonstrate with a simple metal/metal-ion electrode system. When a metal is immersed in a solution containing its ion, metal ions will cross the metal/solution interface. They will pass from the phase where the chemical energy of the ion is large to the phase where the chemical energy of the ion is smaller. Depending on the system, this can occur in either direction. However, only the positively charged cations can pass through the interface. The negatively charged electrode cannot pass into the solution, and the anions cannot pass into the metal. Consequently, charge accumulation occurs at the interface forming an electrical double layer. Consider an example when the metal ions move preferentially from the metal into the solution: the metal surface becomes negatively charged because of the accumulation of the electrons left behind, while the solution layer near the metal surface becomes positively charged because of the accumulation of silver ions. This process produces a potential difference between the two phases that will slow and eventually stop the passage of the metal ions. At equilibrium, the chemical driving force and the opposing electrical force are equal. The potential difference between the metal and the solution phases under these conditions is the equilibrium potential difference. This potential difference cannot be measured because there is no way to make an electrical connection to the solution phase without setting up another electrode potential. Consequently, electrode potentials are always measured against a reference electrode whose potential is known on an arbitrary scale. 
The electric field can be measured in the form of the potential difference (corrosion potential) between the metal and the reference electrode by connecting one lead of a high impedance voltmeter to the metal and the other lead to the reference electrode. The potential of the stainless steel relative to the SCE were collected as negative values. Nowadays, equipotential counter mapping wheel is the principle electrochemical technique applied to the routine inspection of reinforced concrete structures. 


\section{CHAPTER 4}

\section{RESULTS AND DISCUSSION}

The corrosion potential measurements of stainless steel clad end cut 3" inches long rebar during the experiment were collected in Table 1 and represented as time verses potential (SCE) plot in figure 6. Visual observations were recorded to determine any corrosion sign after 16 days. The potential corrosion measurements verses a Saturated Calomel Electrode for the end cut 3" long stainless steel rebar in $0.5 \mathrm{NaCl}$ \& Saturated Pore Solution, $0.25 \mathrm{NaCl}$ \& SPS, $0.5 \mathrm{NaCl}$, and $0.25 \mathrm{NaCl}$ increased from $-0.449 \sim-0.615$ to more negative values 16 days later. Corrosion of the specimens could be seen in figures 7 through 10 . Corrosion was observed at the end cut of the rebar particularly at the core steel.

Effect of bending the stainless steel clad rebar was investigated by suspending bent rebars with 3 and 4 inches diameter. The $U$ shape rebars were exposed to $0.5 \mathrm{~N} \mathrm{NaCl}$. Potential change was used to determine the onset of corrosion. Table 2 lists the corrosion potential measurement and figure 11 indicate the experimental results plot for comparison.

The behavior of stainless steel $316 \mathrm{~L}$ plates in Simulated Pore Solution (SPS), $0.5 \mathrm{NaCl}, \mathrm{NaCl} \& \mathrm{SPS}, \mathrm{NaCl} \& \mathrm{Ca}(\mathrm{OH})_{2}$, and Saturated $\mathrm{Ca}(\mathrm{OH})_{2}$ was 
studied by using the potential corrosion measurement. The data are shown in table $3 A, B, C$ and $D$ while the plots are shown in figure 12 . Another set of the same experiment was conducted by adding $5 \mathrm{gm}$ of sand. The data are shown in table $4 A, B, C$ while the plots are shown in figure 13 . When crevice corrosion occurs the potential decreases from around $-0.125 \mathrm{~V}$ to more negative values. The potential has not reached the corrosion potential value yet. This is because stainless steel is the most important passive materials. Passivity is due to a thin surface film whose composition and structure have been determined exhaustively for various passivating treatments. For most purposes, the passive film can be considered as $2 \mathrm{~nm}$ of microcrystalline chromium oxide $\left(\mathrm{Cr}_{2} \mathrm{O}_{3}\right)$. The $\mathrm{Cr}$, Mo and $\mathrm{N}$ contents of the alloy greatly influence their pitting and crevice corrosion behavior.

The mechanism of crevice corrosion of stainless steels in chloride solutions is an anodic dissolution and the accompanying cathodic oxygen reduction reaction occurs both outside and within the crevice area. Therefore, the original oxygen present in the crevice is used up and the crevice becomes a local anode with the passive current within the crevice balanced by oxygen reduction on the passive surface outside the crevice. Metal ions produced within the crevice are only transported slowly out of the crevice, by diffusion and migration, and hydrolysis of these ions leads to a gradual $\mathrm{pH}$ decrease within the crevice. 
The metal ions thus generated in the crevice will have a positive charge, and to maintain charge neutrality metal ions will migrate out and chloride ions will migrate into the crevice. Electroneutrality ensures the migration of $\mathrm{Cl}^{-}$ions into the crevice and development of an aggressive local solution, as in the local acidification of pits.

When the environment within the crevice reaches a critical crevice solution composition (CCS), the passive film becomes unstable and breaks down leading to general corrosion within the crevice. Microscopic observation of the samples should be considered. The passive films can be described by a three factor model: a hydrated layer in contact with solution, an oxide layer consisting of $\mathrm{Fe}$ and $\mathrm{Cr}$ oxides and a metallic layer enriched in $\mathrm{Ni}$. Increasing the molybdenum content within the alloy or potential movement in the active direction has a significant and beneficial effect on the resistance to breakdown of the passive film, especially for pitting corrosion by altering the distribution and the susceptibility of weak points in the passive film, with little change in the macrocharacteristics of the film. For lower potential the surface films contains lower oxides state of components such as $\mathrm{Cr}^{3+}$, oxy hydroxide and small concentration of $\mathrm{Fe}^{3+}$, as well as an increased total content of oxide.

In the experiment of evaluating the $\mathrm{DCl}$ inhibitor behavior, an end cut 3 " long rebar was used. Potential corrosion measurement, solutions and the concentration of the inhibitor were listed in table $5 \mathrm{~A}$ and $\mathrm{B}$. Visual examination can be seen in figures 14 through 29 while the plot is shown in figure 30 . The 
protection mechanism of the calcium nitrite is the initiation of competing oxidation reaction at the surface of the steel, which regenerate the passivating layer with $\mathrm{Fe}_{2} \mathrm{O}_{3}$. Thus if ferrous ions are produced, calcium nitrite changes them to a stable passive layer. Addition of calcium nitrite made the corrosion potential remains in the passive values. The nitrite ions rapidly oxides ferrous ions to ferric, blocking further passage of ferrous ion from steel into the electrolyte. 


\section{Conclusions}

Over a period longer than one year, potential measurement indicated that no initiation of crevice corrosion of stainless steel 316 occurred in a concrete environment.

Creating crevices by adding sand did not change crevice corrosion behavior of 316 stainless steel in concrete environments for periods of one year.

$\mathrm{DCl}$ had an inhibiting effect and retarded corrosion of the end cut of the clad rebar in the usual additive concentrations to a concrete environment.

Potential measurement indicated that bending of the stainless steel clad rebar did not lead to cracks in the cladding so the usual fabrication methods can be applied to this material. 


\section{Recommendation and Future Work}

It is apparent after more than two years of testing that the exposure period did not provide sufficient time for crevice corrosion initiation to occur in the majority of the specimens under this research. The stainless steel $316 \mathrm{~L}$ plate specimens should be monitored on continuing basis, with corrosion potential measurement approximately once every 2 weeks.

Further evaluation of stainless steel clad rebar in real concrete according to the ASTM G 109 test procedure "Standard Test Method for Determining the Effects of Chemical Admixtures on the Corrosion of Embedded Steel Reinforcement in Concrete Exposed to Chloride Environments". Samples of stainless steel clad, bent stainless steel rebar, and traditional rebar as shown in figure 31,32 and 33 . The diameters of the bent rebar are 5, 4 and 2.5 inches. In addition to corrosion test specimens, it is apparent that evaluation of field applications of the commercially available corrosion inhibitors with different levels. The dynamic fatigue response of the stainless steel clad rebar should be also investigated after breaking the passive film to determine the affect of the crevice corrosion rate in the concrete environment. 


\begin{tabular}{|c|c|c|c|c|}
\hline \multirow{2}{*}{$\begin{array}{l}\text { Time } \\
\text { (days) }\end{array}$} & \multicolumn{4}{|c|}{$\begin{array}{l}\text { Testing Solutions for End Cut } 3 \text { “ Long Rebar } \\
\text { Without } \mathrm{DCl} \text { Inhibitor }\end{array}$} \\
\hline & $\begin{array}{l}0.5 \mathrm{~N} \mathrm{NaCl} \\
\& \text { SPS }\end{array}$ & $\begin{array}{l}0.25 \mathrm{~N} \mathrm{NaCl} \\
\& \text { SPS }\end{array}$ & $0.5 \mathrm{~N} \mathrm{NaCl}$ & $0.25 \mathrm{~N} \mathrm{NaCl}$ \\
\hline 1 & -0.504 & -0.449 & -0.615 & -0.557 \\
\hline 2 & -0.576 & -0.538 & -0.661 & -0.651 \\
\hline 4 & -0.637 & -0.631 & -0.675 & -0.662 \\
\hline 6 & -0.642 & -0.639 & -0.656 & -0.662 \\
\hline 9 & -0.635 & -0.646 & -0.664 & -0.656 \\
\hline 12 & -0.646 & -0.646 & -0.663 & -0.656 \\
\hline 16 & -0.645 & -0.637 & -0.666 & -0.657 \\
\hline
\end{tabular}

Table 1. Average of 3 sample sets of corrosion potential ( $m$ V SCE) for end cut 3 " long rebar in testing solutions with different concentration of $\mathrm{NaCl}$ without $\mathrm{DCl}$ inhibitor. 


\begin{tabular}{|c|c|c|}
\hline \multirow{2}{*}{$\begin{array}{c}\text { Time } \\
\text { (days) }\end{array}$} & \multicolumn{2}{|c|}{ Testing Solution (U Shape rebar) } \\
\cline { 2 - 3 } & \multicolumn{2}{|c|}{$0.5 \mathrm{~N} \mathrm{NaCl}$} \\
\hline 1 & -0.140 & 4" Diameter \\
\hline 4 & -0.039 & -0.195 \\
\hline 7 & -0.109 & -0.042 \\
\hline 12 & -0.044 & -0.032 \\
\hline 17 & -0.117 & -0.102 \\
\hline
\end{tabular}

Table 2. corrosion potential ( $m V$ SCE) for $U$ shape rebar samples exposed to $0.5 \mathrm{~N} \mathrm{NaCl}$ testing solution. 


\begin{tabular}{|c|c|c|c|c|c|}
\hline \multirow{2}{*}{$\begin{array}{c}\text { Time } \\
\text { (days) }\end{array}$} & \multicolumn{5}{|c|}{ Testing Solutions (No Sand) } \\
\cline { 2 - 6 } & S P S & $0.5 \mathrm{~N} \mathrm{NaCl}$ & $\begin{array}{c}0.5 \mathrm{~N} \mathrm{NaCl} \& \\
\text { SPS }\end{array}$ & $\begin{array}{c}0.5 \mathrm{~N} \mathrm{NaCl} \& \\
\mathrm{Ca}(\mathrm{OH})^{2}\end{array}$ & $\begin{array}{c}\text { Saturated } \\
\mathrm{Ca}(\mathrm{OH})^{2}\end{array}$ \\
\hline 1 & -0.254 & -0.099 & -0.268 & -0.314 & -0.073 \\
\hline 3 & -0.243 & -0.045 & 0.051 & -0.204 & -0.212 \\
\hline 6 & -0.211 & 0.095 & 0.034 & -0.203 & -0.2 \\
\hline 8 & -0.2 & 0.094 & 0.036 & -0.197 & -0.2 \\
\hline 14 & -0.185 & 0.116 & -0.19 & 0.19 & 0.052 \\
\hline 18 & -0.176 & 0.123 & -0.192 & -0.181 & 0.057 \\
\hline 21 & -0.159 & 0.033 & -0.194 & -0.18 & 0.063 \\
\hline 24 & -0.162 & 0.065 & -0.184 & -0.181 & 0.057 \\
\hline 28 & -0.164 & 0.063 & -0.187 & -0.171 & 0.063 \\
\hline 33 & -0.16 & 0.015 & 0.181 & -0.139 & 0.073 \\
\hline 38 & -0.149 & 0.011 & -0.184 & -0.118 & 0.08 \\
\hline
\end{tabular}

Table 3A. Average of 3 sample sets of corrosion potential ( $\mathrm{mV}$ SCE) for stainless steel 316 plates in testing solutions with and without addition of $0.5 \mathrm{~N} \mathrm{NaCl}$. 


\begin{tabular}{|c|c|c|c|c|c|}
\hline \multirow{2}{*}{$\begin{array}{c}\text { Time } \\
\text { (days) }\end{array}$} & \multicolumn{5}{|c|}{ Testing Solutions (No Sand) } \\
\cline { 2 - 6 } & S P S & $0.5 \mathrm{~N} \mathrm{NaCl}$ & $\begin{array}{c}0.5 \mathrm{~N} \mathrm{NaCl} \\
\text { \& SPS }\end{array}$ & $\begin{array}{c}0.5 \mathrm{~N} \mathrm{NaCl} \& \\
\mathrm{Ca}(\mathrm{OH})^{2}\end{array}$ & $\begin{array}{c}\text { Saturated } \\
\mathrm{Ca}(\mathrm{OH})^{2}\end{array}$ \\
\hline 42 & -0.15 & -0.006 & -0.179 & -0.09 & 0.089 \\
\hline 52 & -0.146 & 0.077 & -0.174 & -0.055 & 0.051 \\
\hline 55 & -0.142 & 0.023 & -0.172 & -0.046 & 0.058 \\
\hline 58 & -0.139 & 0.012 & -0.17 & -0.227 & 0.079 \\
\hline 62 & -0.142 & 0.005 & -0.172 & -0.224 & 0.091 \\
\hline 69 & -0.136 & 0.008 & -0.169 & -0.2 & 0.101 \\
\hline 76 & -0.144 & 0.01 & -0.155 & -0.168 & 0.1 \\
\hline 81 & -0.145 & 0.017 & -0.15 & -0.153 & 0.099 \\
\hline 86 & -0.153 & 0.006 & -0.14 & -0.149 & 0.088 \\
\hline 91 & -0.14 & 0.011 & -0.145 & -0.117 & 0.098 \\
\hline 97 & -0.138 & 0.01 & -0.131 & -0.109 & 0.088 \\
\hline
\end{tabular}

Table 3B. Average of 3 sample sets of corrosion potential ( $m V$ SCE) for stainless steel 316 plates in testing solutions with and without addition of $0.5 \mathrm{~N} \mathrm{NaCl}$. 


\begin{tabular}{|c|c|c|c|c|c|}
\hline \multirow{2}{*}{$\begin{array}{c}\text { Time } \\
\text { (days) }\end{array}$} & \multicolumn{5}{|c|}{ Testing Solutions (No Sand) } \\
\cline { 2 - 6 } & S P S & $0.5 \mathrm{~N} \mathrm{NaCl}$ & $\begin{array}{c}0.5 \mathrm{~N} \mathrm{NaCl} \\
\text { \& SPS }\end{array}$ & $\begin{array}{c}0.5 \mathrm{~N} \mathrm{NaCl} \& \\
\mathrm{Ca}(\mathrm{OH})^{2}\end{array}$ & $\begin{array}{c}\text { Saturated } \\
\mathrm{Ca}(\mathrm{OH})^{2}\end{array}$ \\
\hline 104 & -0.142 & 0.033 & -0.15 & -0.087 & 0.101 \\
\hline 117 & -0.1 & 0.032 & -0.118 & 0.018 & 0.154 \\
\hline 126 & -0.126 & 0.025 & -0.1 & -0.024 & 0.124 \\
\hline 133 & -0.141 & 0.051 & -0.128 & -0.007 & 0.111 \\
\hline 142 & -0.134 & 0.087 & -0.065 & -0.029 & 0.074 \\
\hline 152 & -0.143 & 0.083 & -0.138 & -0.034 & 0.095 \\
\hline 167 & -0.136 & 0.082 & -0.14 & -0.036 & 0.101 \\
\hline 182 & -0.104 & 0.088 & -0.119 & -0.028 & 0.073 \\
\hline 200 & -0.095 & 0.101 & -0.122 & -0.024 & 0.065 \\
\hline 216 & -0.085 & 0.105 & -0.122 & -0.03 & 0.093 \\
\hline 230 & -0.128 & 0.106 & -0.139 & -0.046 & 0.098 \\
\hline
\end{tabular}

Table 3C. Average of 3 sample sets of corrosion potential ( $m$ V SCE) for stainless steel 316 plates in testing solutions with and without addition of $0.5 \mathrm{~N} \mathrm{NaCl}$. 


\begin{tabular}{|c|c|c|c|c|c|}
\hline \multirow{2}{*}{$\begin{array}{c}\text { Time } \\
\text { (days) }\end{array}$} & \multicolumn{5}{|c|}{ Testing Solutions (No Sand) } \\
\cline { 2 - 6 } & S P S & $0.5 \mathrm{~N} \mathrm{NaCl}$ & $\begin{array}{c}0.5 \mathrm{~N} \mathrm{NaCl} \\
\text { \& SPS }\end{array}$ & $\begin{array}{c}0.5 \mathrm{~N} \mathrm{NaCl} \& \\
\mathrm{Ca}(\mathrm{OH})^{2}\end{array}$ & $\begin{array}{c}\text { Saturated } \\
\mathrm{Ca}(\mathrm{OH})^{2}\end{array}$ \\
\hline 240 & -0.129 & 0.114 & -0.14 & -0.031 & 0.119 \\
\hline 251 & -0.094 & 0.117 & -0.14 & -0.033 & 0.098 \\
\hline 266 & -0.128 & 0.141 & -0.146 & -0.023 & 0.094 \\
\hline 287 & -0.078 & 0.141 & -0.079 & -0.026 & 0.117 \\
\hline 300 & -0.091 & 0.099 & -0.078 & -0.013 & 0.013 \\
\hline 310 & -0.090 & 0.095 & -0.083 & -0.011 & 0.109 \\
\hline 330 & -0.053 & 0.098 & -0.088 & -0.016 & 0.095 \\
\hline 345 & -0.028 & 0.093 & 0.073 & -0.023 & 0.094 \\
\hline 379 & -0.058 & 0.079 & -0.088 & -0.036 & 0.083 \\
\hline 389 & -0.058 & 0.083 & -0.084 & -0.040 & 0.094 \\
\hline 365 & 0.129 & 0.210 & 0.041 & 0.104 & 0.189 \\
\hline
\end{tabular}

Table 3D. Average of 3 sample sets of corrosion potential ( $\mathrm{mV} \mathrm{SCE}$ ) for stainless steel 316 plates in testing solutions with and without addition of $0.5 \mathrm{~N} \mathrm{NaCl}$. 


\begin{tabular}{|c|c|c|c|c|c|}
\hline \multirow{2}{*}{$\begin{array}{c}\text { Time } \\
\text { (days) }\end{array}$} & \multicolumn{4}{|c}{ Testing Solutions With Addition of 5 gm of Sand } \\
\cline { 2 - 6 } & S P S & $0.5 \mathrm{~N} \mathrm{NaCl}$ & $\begin{array}{c}\mathrm{NaCl} \& \\
\text { SPS }\end{array}$ & $\begin{array}{c}\mathrm{NaCl} \& \\
\mathrm{Ca}(\mathrm{OH})^{2}\end{array}$ & $\begin{array}{c}\text { Sat'd } \\
\mathrm{Ca}(\mathrm{OH})^{2}\end{array}$ \\
\hline 1 & -0.226 & 0.048 & -0.243 & -0.278 & 0.002 \\
\hline 3 & -0.229 & 0.041 & -0.228 & -0.256 & -0.011 \\
\hline 6 & -0.229 & 0.044 & -0.226 & -0.255 & -0.016 \\
\hline 10 & -0.226 & 0.043 & -0.23 & -0.254 & -0.017 \\
\hline 17 & -0.194 & 0.062 & -0.228 & -0.239 & -0.005 \\
\hline 24 & -0.188 & 0.023 & -0.202 & -0.222 & -0.007 \\
\hline 29 & -0.168 & 0.014 & -0.218 & -0.203 & -0.002 \\
\hline 34 & -0.17 & 0.007 & -0.21 & -0.182 & -0.008 \\
\hline 39 & -0.15 & 0.007 & -0.215 & -0.164 & 0.012 \\
\hline 45 & -0.133 & -0.001 & -0.205 & -0.145 & 0.004 \\
\hline 52 & -0.136 & 0.008 & -0.207 & -0.122 & 0.012 \\
\hline
\end{tabular}

Table 4A. Average of 3 sample sets of corrosion potential ( $m V$ SCE) for stainless steel 316 plates in testing solutions with and without addition of $0.5 \mathrm{~N} \mathrm{NaCl}$. 


\begin{tabular}{|c|c|c|c|c|c|}
\hline \multirow{2}{*}{$\begin{array}{c}\text { Time } \\
\text { (days) }\end{array}$} & \multicolumn{4}{|c}{ Testing Solutions With Addition of 5 gm of Sand } \\
\cline { 2 - 6 } & S P S & $0.5 \mathrm{~N} \mathrm{NaCl}$ & $\begin{array}{c}\mathrm{NaCl} \& \\
\text { SPS }\end{array}$ & $\begin{array}{c}\mathrm{NaCl} \& \\
\mathrm{Ca}(\mathrm{OH})_{2}\end{array}$ & $\begin{array}{c}\text { Sat'd } \\
\mathrm{Ca}(\mathrm{OH})_{2}\end{array}$ \\
\hline 65 & -0.051 & 0.032 & -0.16 & -0.022 & 0.036 \\
\hline 74 & -0.095 & 0.012 & -0.133 & -0.054 & 0.03 \\
\hline 81 & -0.083 & 0.02 & -0.172 & -0.073 & 0.016 \\
\hline 90 & -0.1 & 0.023 & -0.175 & -0.056 & 0.021 \\
\hline 100 & -0.103 & 0.012 & -0.163 & -0.071 & 0.008 \\
\hline 115 & -0.079 & 0.006 & -0.141 & -0.062 & -0.006 \\
\hline 130 & -0.048 & 0.02 & -0.142 & -0.035 & -0.006 \\
\hline 148 & -0.047 & 0.021 & -0.148 & -0.033 & -0.004 \\
\hline 164 & -0.083 & 0.024 & -0.14 & -0.029 & 0.038 \\
\hline 178 & -0.096 & 0.015 & -0.162 & -0.031 & 0.017 \\
\hline 188 & -0.071 & 0.01 & -0.156 & -0.045 & 0.01 \\
\hline
\end{tabular}

Table 4B. Average of 3 sample sets of corrosion potential (mV SCE) for stainless steel 316 plates in testing solutions with and without addition of $0.5 \mathrm{~N} \mathrm{NaCl}$. 


\begin{tabular}{|c|c|c|c|c|c|}
\hline \multirow{2}{*}{$\begin{array}{c}\text { Time } \\
\text { (days) }\end{array}$} & \multicolumn{4}{|c}{ Testing Solutions With Addition of 5 gm of Sand } \\
\cline { 2 - 6 } & S P S & $0.5 \mathrm{~N} \mathrm{NaCl}$ & $\begin{array}{c}\mathrm{NaCl} \& \\
\mathrm{SPS}\end{array}$ & $\begin{array}{c}\mathrm{NaCl} \& \\
\mathrm{Ca}(\mathrm{OH})_{2}\end{array}$ & $\begin{array}{c}\mathrm{Sat} \mathrm{d} \\
\mathrm{Ca}(\mathrm{OH})_{2}\end{array}$ \\
\hline 199 & -0.073 & 0.005 & -0.142 & -0.047 & 0.002 \\
\hline 214 & -0.058 & 0.021 & -0.169 & -0.026 & 0.038 \\
\hline 235 & -0.023 & 0.043 & -0.077 & -0.022 & 0.055 \\
\hline 248 & -0.021 & 0.051 & -0.113 & -0.015 & 0.055 \\
\hline 278 & -0.038 & 0.036 & -0.118 & -0.029 & 0.037 \\
\hline 293 & -0.067 & 0.025 & -0.126 & -0.045 & 0.016 \\
\hline 313 & -0.056 & 0.040 & -0.126 & -0.053 & 0.026 \\
\hline 327 & 0.083 & 0.147 & 0.008 & 0.093 & 0.067 \\
\hline 340 & -0.045 & 0.017 & -0.126 & -0.044 & 0.013 \\
\hline 350 & -0.049 & 0.023 & -0.126 & -0.048 & 0.021 \\
\hline
\end{tabular}

Table 4C. Average of 3 sample sets of corrosion potential (mV SCE) for stainless steel 316 plates in testing solutions with and without addition of $0.5 \mathrm{~N} \mathrm{NaCl}$. 


\begin{tabular}{|c|c|c|c|c|c|c|c|c|}
\hline \multirow[b]{2}{*}{$\begin{array}{l}\text { Time } \\
\text { (days) }\end{array}$} & \multicolumn{8}{|c|}{$\begin{array}{l}\text { Testing Solutions for End Cut } 3 \text { “ Long Rebar With DCI } \\
\text { Inhibitor }\end{array}$} \\
\hline & $\begin{array}{c}0.5 \mathrm{~N} \\
\mathrm{NaCL} \\
+ \\
\mathrm{SPS} \\
+ \\
0.25 \mathrm{~N} \\
\mathrm{DCl}\end{array}$ & $\begin{array}{c}0.25 \mathrm{~N} \\
\mathrm{NaCL} \\
+ \\
\mathrm{SPS} \\
+ \\
0.25 \mathrm{~N} \\
\mathrm{DCl} \\
\end{array}$ & $\begin{array}{c}0.5 \mathrm{~N} \\
\mathrm{NaCl} \\
+ \\
0.25 \mathrm{~N} \\
\mathrm{DCl}\end{array}$ & $\begin{array}{c}0.25 \mathrm{~N} \\
\mathrm{NaCL} \\
+ \\
0.25 \mathrm{~N} \\
\mathrm{DCl}\end{array}$ & $\begin{array}{c}0.5 \mathrm{~N} \\
\mathrm{NaCl} \\
+ \\
\mathrm{SPS} \\
+ \\
0.5 \mathrm{~N} \\
\mathrm{DCl} \\
\end{array}$ & $\begin{array}{c}0.25 \mathrm{~N} \\
\mathrm{NaCl} \\
+ \\
\mathrm{SPS} \\
+ \\
0.5 \mathrm{~N} \\
\mathrm{DCl} \\
\end{array}$ & $\begin{array}{c}0.5 \mathrm{~N} \\
\mathrm{NaCL} \\
+ \\
0.5 \mathrm{~N} \\
\mathrm{DCl}\end{array}$ & $\begin{array}{c}0.25 \mathrm{~N} \\
\mathrm{NaCL} \\
+ \\
0.5 \mathrm{~N} \\
\mathrm{DCl}\end{array}$ \\
\hline 1 & -0.261 & -0.213 & -0.272 & -0.112 & -0.294 & -0.25 & -0.221 & -0.099 \\
\hline 2 & -0.219 & -0.175 & -0.167 & -0.111 & -0.203 & -0.232 & -0.182 & -0.144 \\
\hline 5 & -0.184 & -0.129 & -0.105 & -0.08 & -0.183 & -0.129 & -0.114 & -0.074 \\
\hline 9 & -0.174 & -0.151 & -0.103 & -0.082 & -0.167 & -0.103 & -0.067 & -0.036 \\
\hline 13 & -0.143 & -0.095 & -0.102 & -0.055 & -0.1 & -0.023 & -0.044 & -0.014 \\
\hline 19 & -0.141 & -0.027 & -0.08 & -0.012 & -0.077 & -0.042 & -0.08 & 0.019 \\
\hline 23 & -0.109 & -0.029 & -0.068 & -0.023 & -0.059 & -0.021 & -0.025 & 0.006 \\
\hline 30 & -0.008 & -0.02 & -0.071 & 0.011 & -0.044 & 0.036 & -0.008 & 0.041 \\
\hline 35 & -0.058 & -0.021 & -0.078 & -0.052 & -0.055 & -0.032 & -0.066 & -0.027 \\
\hline 40 & -0.095 & -0.064 & -0.039 & 0.03 & -0.027 & 0.045 & -0.008 & -0.008 \\
\hline
\end{tabular}

Table 5A. Average of 3 sample sets of corrosion potential ( $m$ V SCE) for end cut 3" long rebar in testing solutions with different concentration of $\mathrm{NaCl}$ and $\mathrm{DCl}$ inhibitor. 


\begin{tabular}{|c|c|c|c|c|c|c|c|c|}
\hline \multirow[b]{2}{*}{$\begin{array}{l}\text { Time } \\
\text { (days) }\end{array}$} & \multicolumn{8}{|c|}{$\begin{array}{l}\text { Testing Solutions for End Cut } 3 \text { “ Long Rebar With DCI } \\
\text { Inhibitor }\end{array}$} \\
\hline & $\begin{array}{c}0.5 \mathrm{~N} \\
\mathrm{NaCL} \\
+ \\
\mathrm{SPS} \\
+ \\
0.25 \mathrm{~N} \\
\mathrm{DCl}\end{array}$ & $\begin{array}{c}0.25 \mathrm{~N} \\
\mathrm{NaCl} \\
+ \\
\mathrm{SPS} \\
+ \\
0.25 \mathrm{~N} \\
\mathrm{DCl} \\
\end{array}$ & $\begin{array}{c}0.5 \mathrm{~N} \\
\mathrm{NaCL} \\
+ \\
0.25 \mathrm{~N} \\
\mathrm{DCl}\end{array}$ & $\begin{array}{c}0.25 \mathrm{~N} \\
\mathrm{NaCL} \\
+ \\
0.25 \mathrm{~N} \\
\mathrm{DCl}\end{array}$ & $\begin{array}{c}0.5 \mathrm{~N} \\
\mathrm{NaCL} \\
+ \\
\mathrm{SPS} \\
+ \\
0.5 \mathrm{~N} \\
\mathrm{DCl}\end{array}$ & $\begin{array}{c}0.25 \mathrm{~N} \\
\mathrm{NaCL} \\
+ \\
\mathrm{SPS} \\
+ \\
0.5 \mathrm{~N} \\
\mathrm{DCl} \\
\end{array}$ & $\begin{array}{c}0.5 \mathrm{~N} \\
\mathrm{NaCL} \\
+ \\
0.5 \mathrm{~N} \\
\mathrm{DCl}\end{array}$ & $\begin{array}{c}0.25 \mathrm{~N} \\
\mathrm{NaCL} \\
+ \\
0.5 \mathrm{~N} \\
\mathrm{DCl}\end{array}$ \\
\hline 55 & -0.072 & -0.026 & -0.052 & 0.048 & -0.035 & 0.001 & 0.016 & 0.065 \\
\hline 65 & -0.041 & -0.009 & -0.029 & 0.039 & -0.019 & 0.021 & 0.030 & 0.069 \\
\hline 75 & -0.021 & 0.047 & 0.001 & 0.012 & 0.027 & 0.074 & 0.046 & 0.075 \\
\hline 88 & 0.012 & 0.040 & 0.011 & 0.067 & 0.022 & 0.077 & 0.030 & 0.049 \\
\hline 98 & -0.009 & 0.052 & 0.014 & 0.057 & 0.040 & 0.079 & 0.053 & 0.069 \\
\hline 118 & -0.035 & 0.040 & 0.014 & 0.062 & 0.013 & 0.075 & 0.021 & 0.032 \\
\hline 133 & 0.013 & 0.023 & 0.019 & 0.074 & 0.063 & 0.051 & 0.044 & 0.060 \\
\hline 153 & 0.099 & 0.133 & 0.1118 & 0.175 & 0.111 & 0.185 & 0.180 & 0.180 \\
\hline 167 & -0.018 & -0.002 & -0.028 & $\begin{array}{c}+0.05 \\
3 \\
\end{array}$ & 0.003 & 0.066 & 0.030 & 0.061 \\
\hline 177 & -0.023 & -0.022 & 0.033 & 0.014 & -0.025 & 0.061 & 0.010 & 0.081 \\
\hline
\end{tabular}

Table 5B. Average of 3 sample sets of corrosion potential ( $m$ V SCE) for end cut 3" long rebar in testing solutions with different concentration of $\mathrm{NaCl}$ and $\mathrm{DCl}$ inhibitor. 


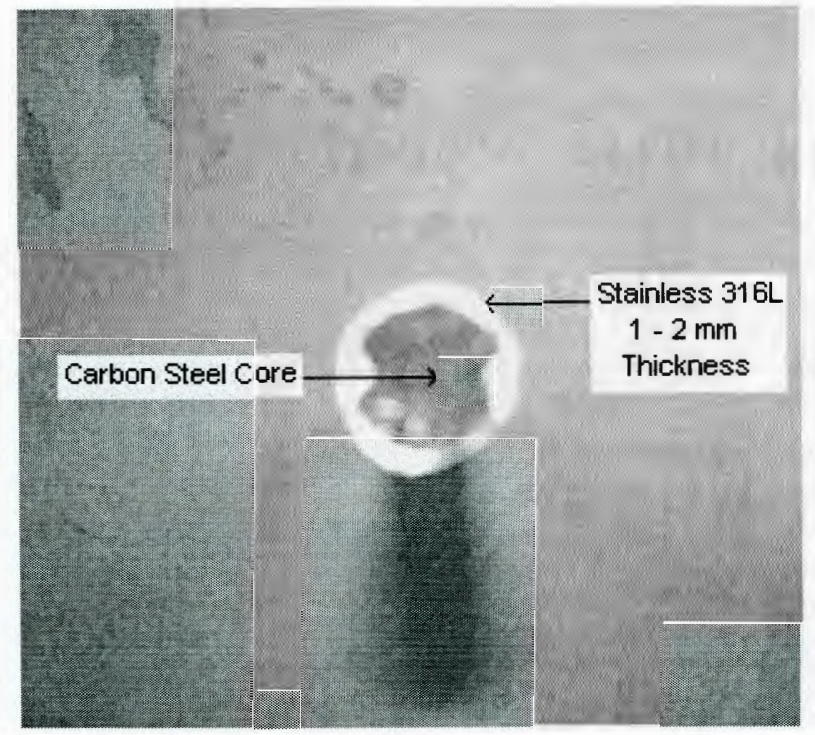

Figure 1. Cross section of stainless steel $316 \mathrm{~L}$ rebar clad around conventional steel core. 


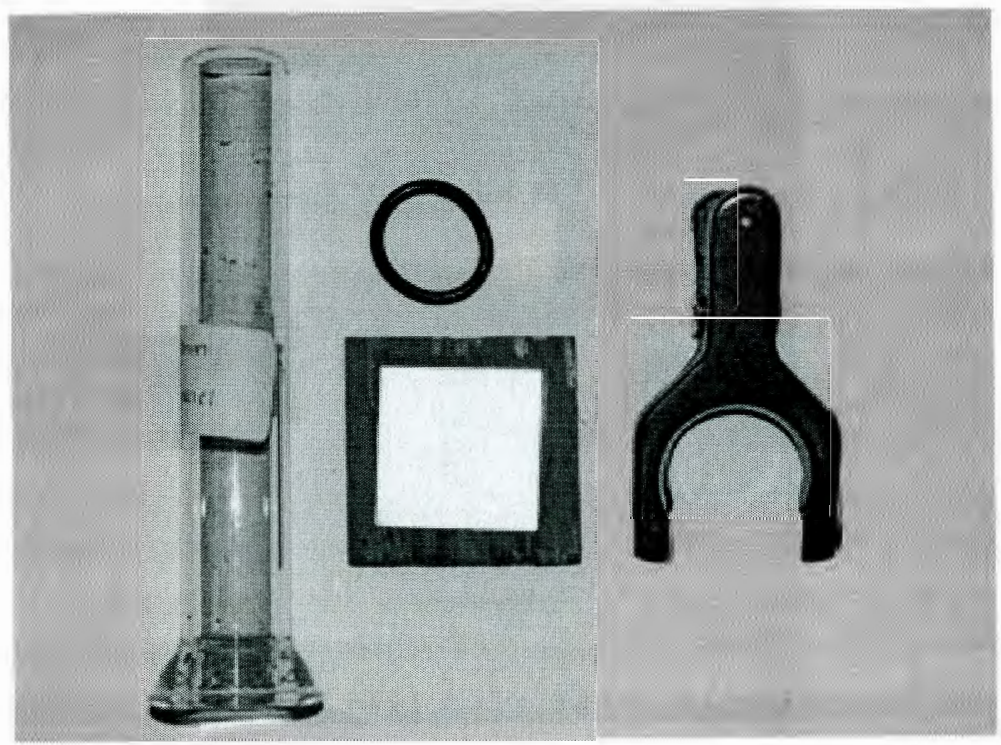

Figure 2. Glass tube, "O" ring and clamp to be clamped onto the surface of the stainless steel plates sample. 


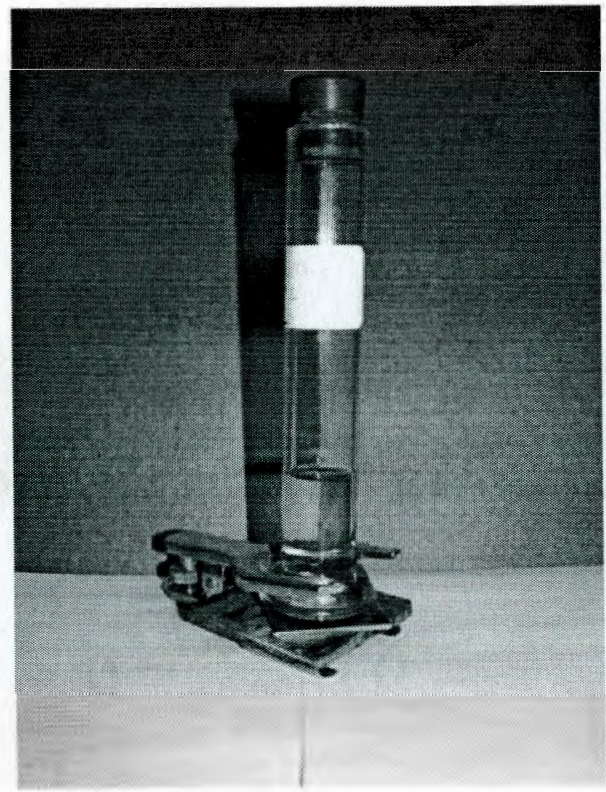

Figure 3. Example of the glass tube clamped onto the surface of the stainless steel 316 plates sample with an exposed area of $5 \mathrm{~cm}^{2}$. 


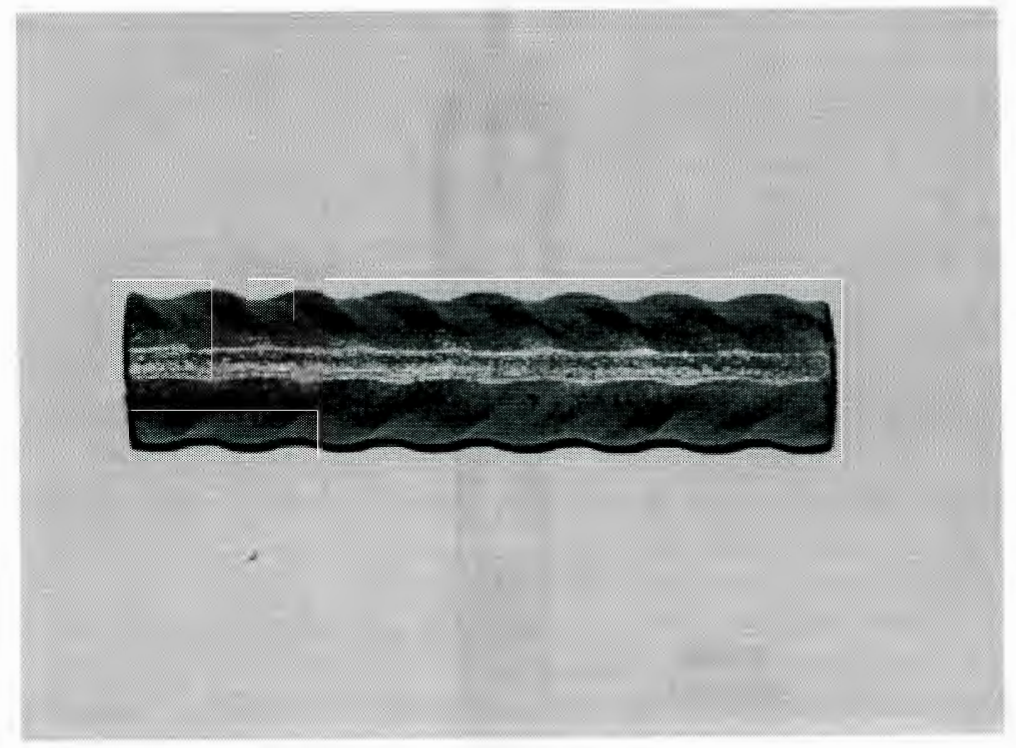

Figure 4. Stainless steel rebar with end cuts, 3" long 


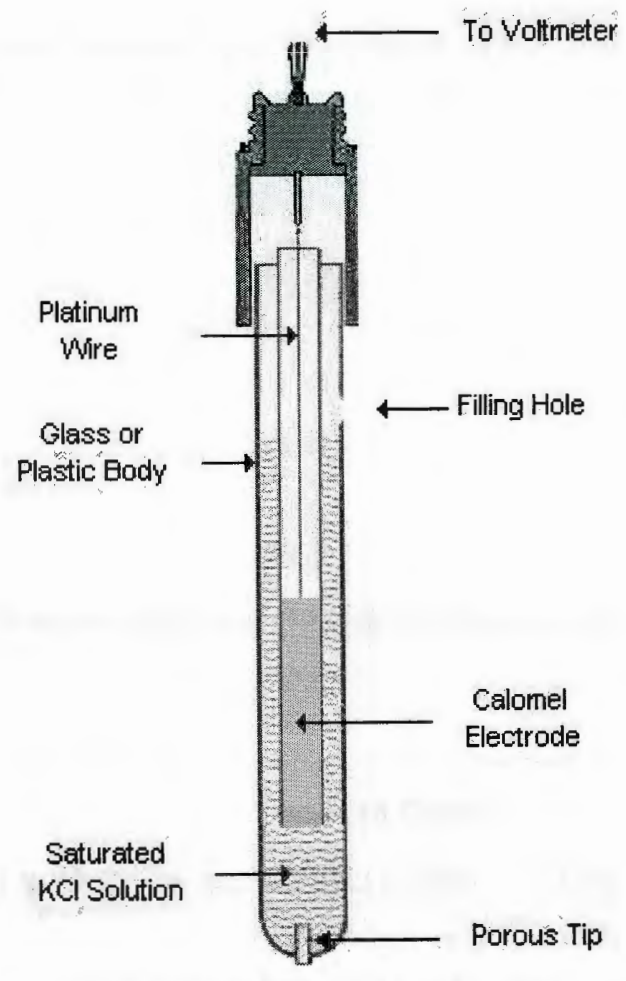

Figure 5. Saturated Calomel Reference Electrode (SCE) 


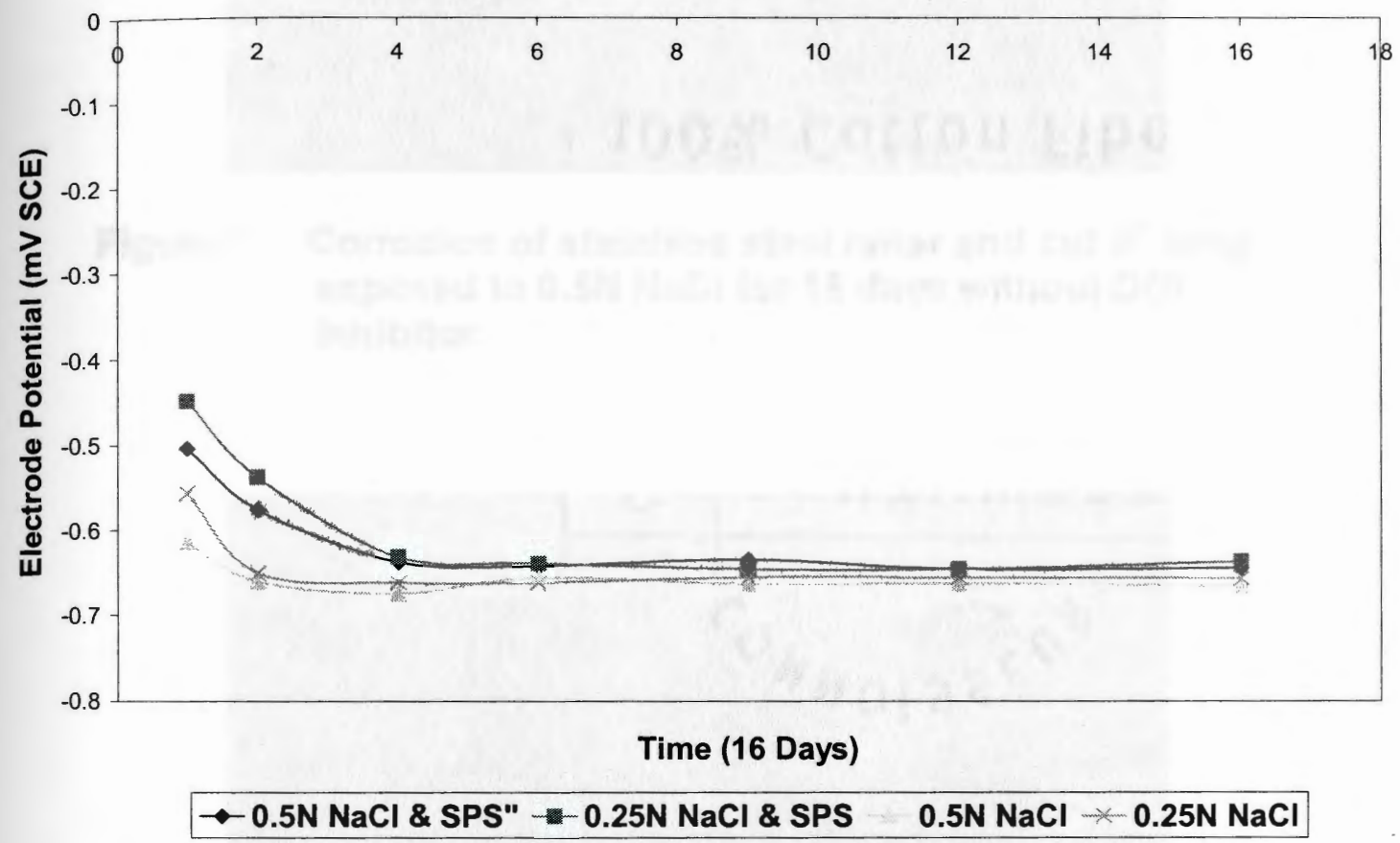

Figure 6. Data average of 3 samples sets of corrosion potential ( $\mathrm{mV} \mathrm{SCE}$ ) verses time for end cut 3" long rebar in different testing solutions. 


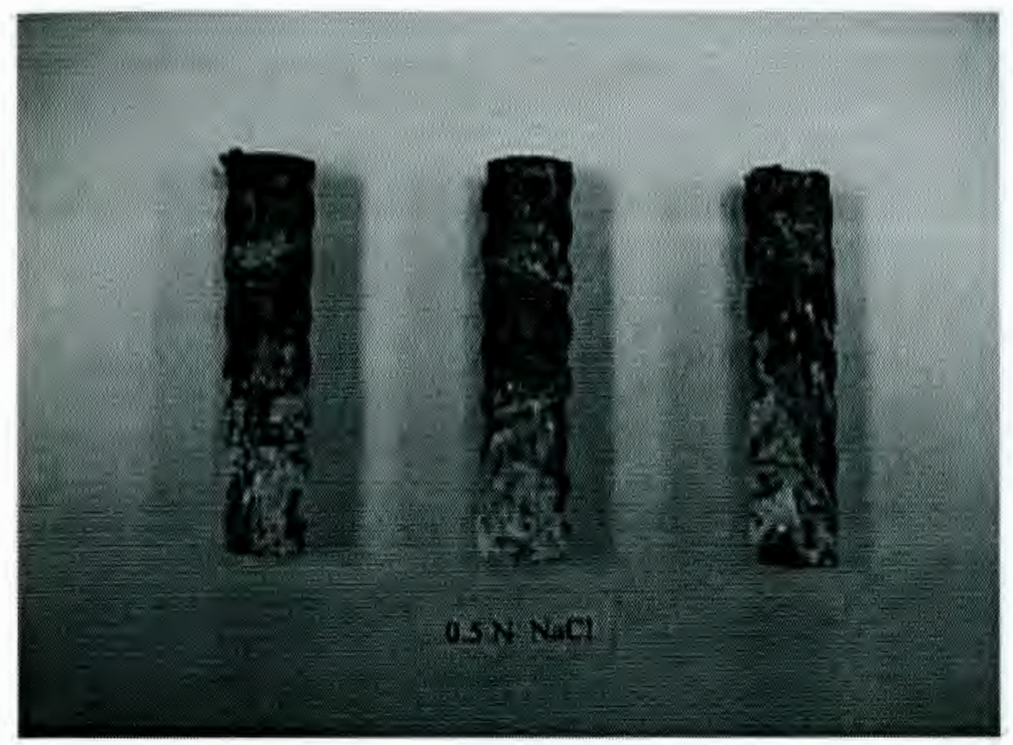

Figure 7. Corrosion of stainless steel rebar end cut 3" long exposed to $0.5 \mathrm{~N} \mathrm{NaCl}$ for 16 days without $\mathrm{DCl}$ inhibitor.

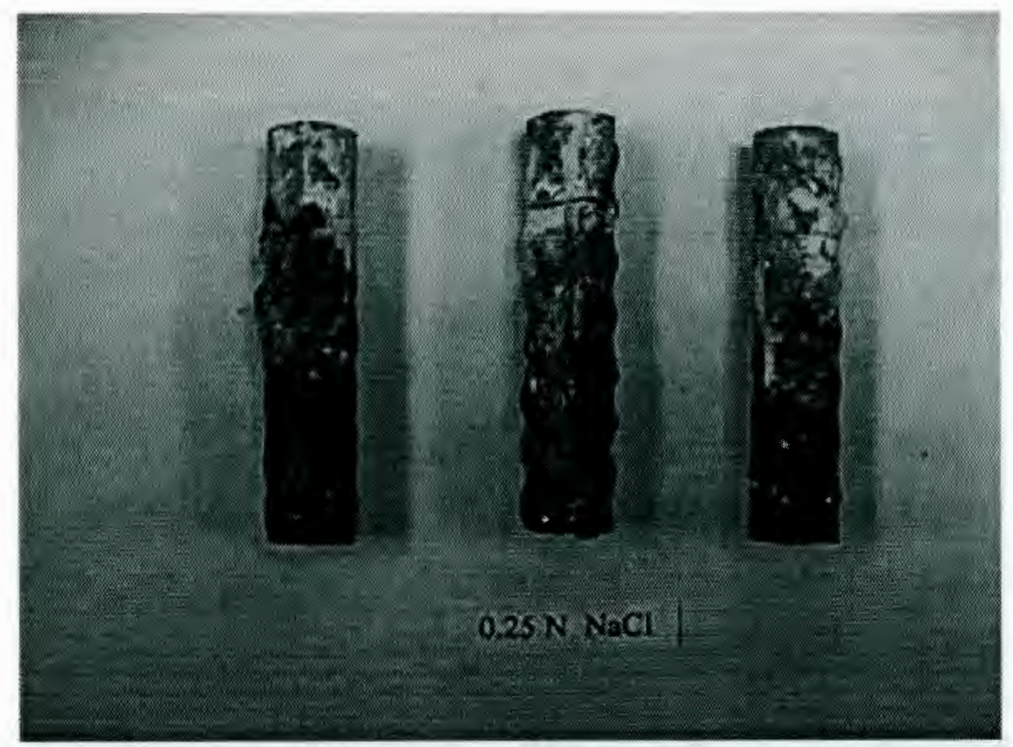

Figure 8. Corrosion of stainless steel rebar end cut 3" long exposed to $0.25 \mathrm{~N} \mathrm{NaCl}$ for 16 days without $\mathrm{DCl}$ inhibitor. 


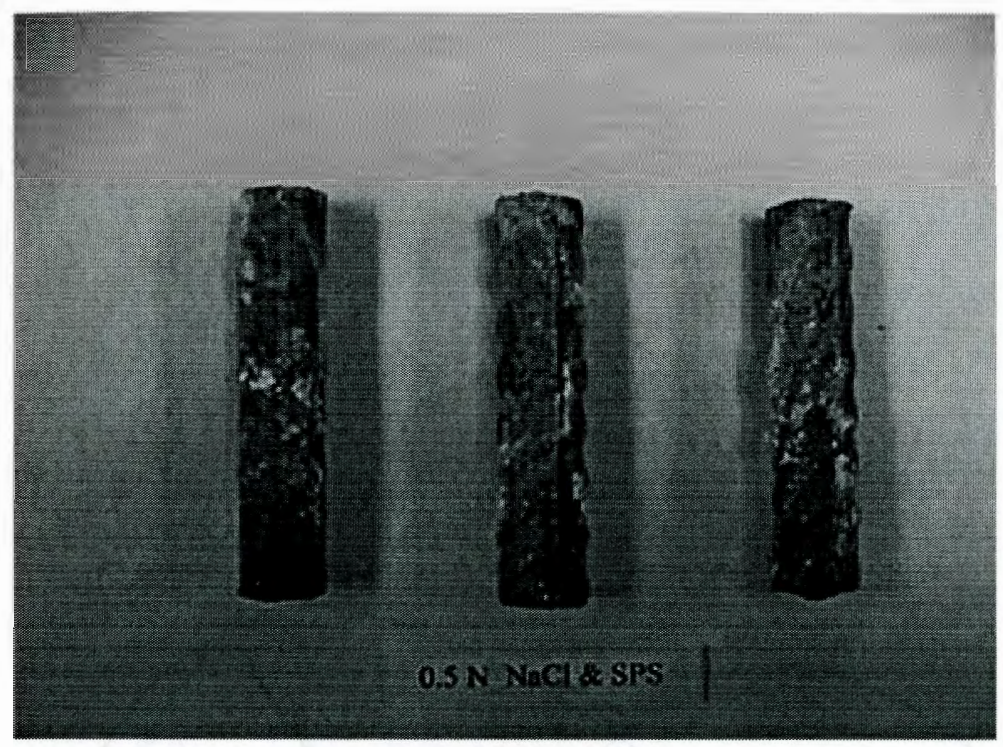

Figure 9. Corrosion of stainless steel rebar end cut 3" long exposed to $0.5 \mathrm{~N} \mathrm{NaCl} \&$ Simulated Pore Solution for 16 days without $\mathrm{DCl}$ inhibitor.

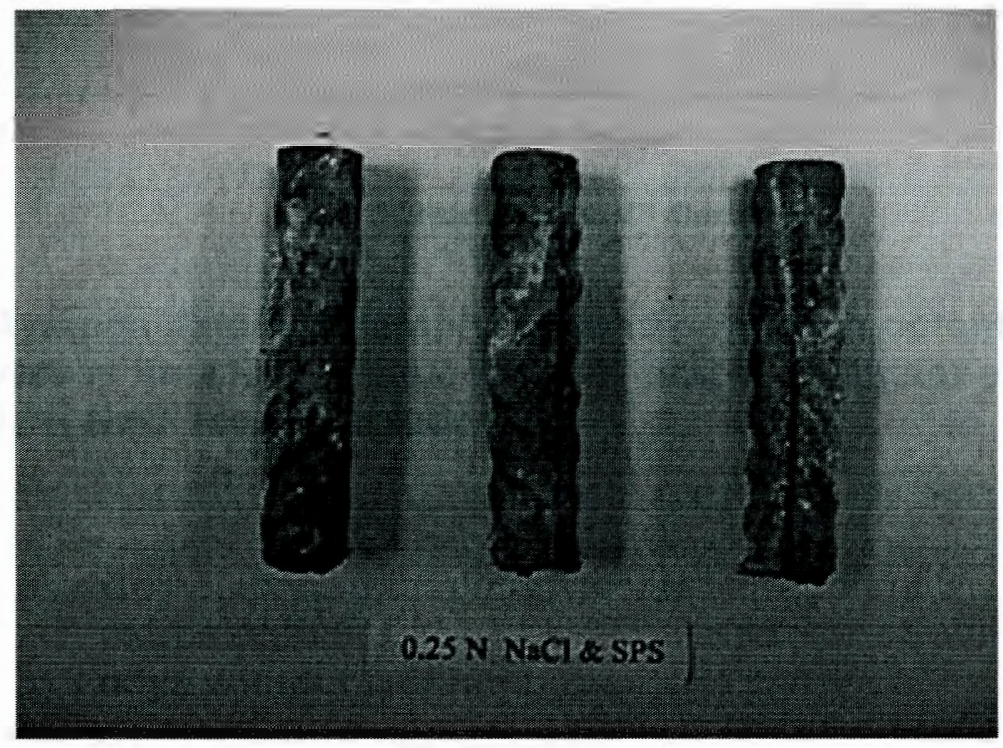

Figure 10. Corrosion of stainless steel rebar end cut 3 " long exposed to $0.25 \mathrm{~N} \mathrm{NaCl} \&$ Simulated Pore Solution for 16 days without $\mathrm{DCl}$ inhibitor. 


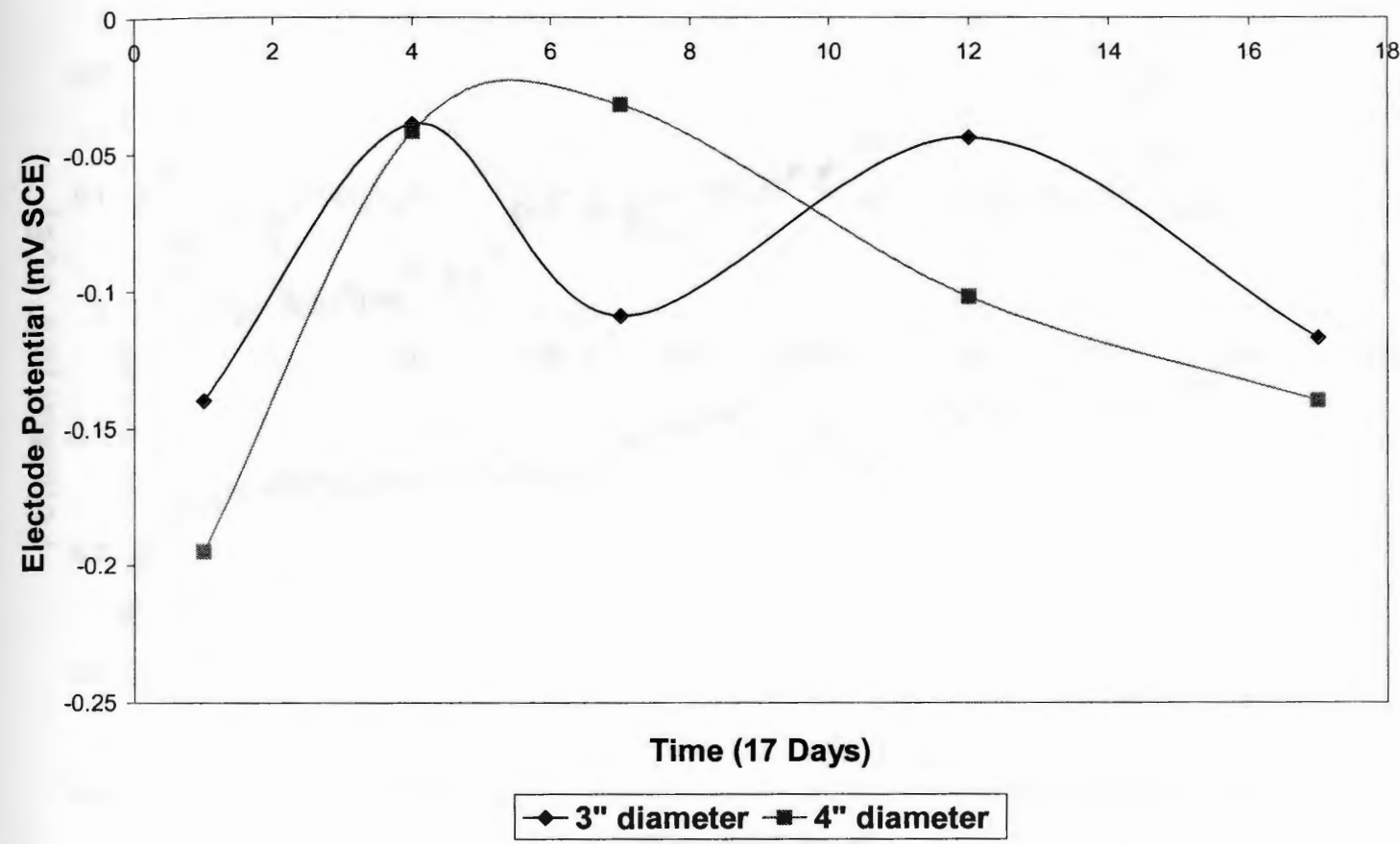

Figure 11. Average data of 3 samples sets of corrosion potential (mV SCE) verses time for U shape rebar 3" and 4" Diameter exposed to $0.5 \mathrm{~N} \mathrm{NaCl}$ testing solution. 


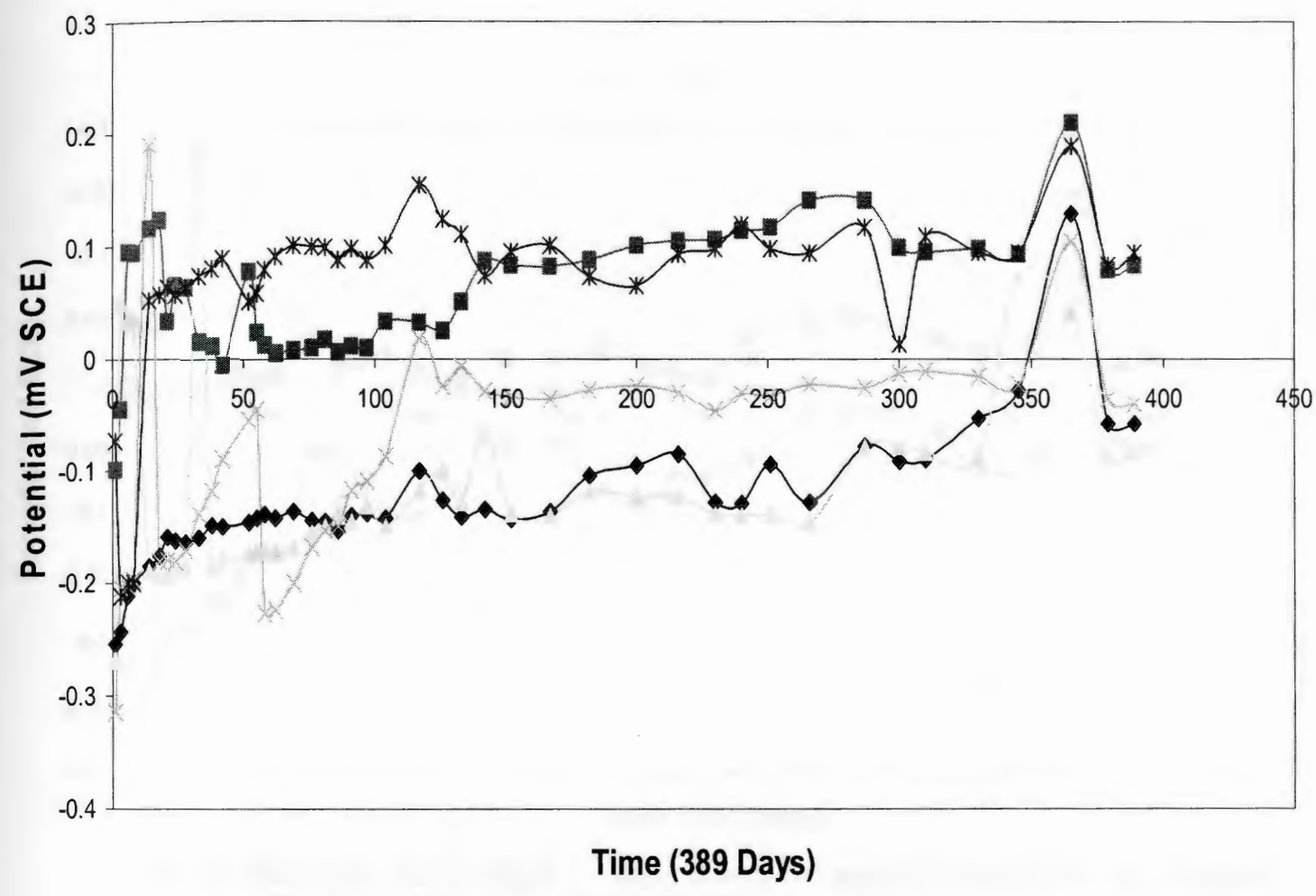

Sim Pore Soln $* 0.5 \mathrm{NaCl} \quad \mathrm{NaCl} \& \mathrm{SPS} * \mathrm{NaCl} \& \mathrm{Ca}(\mathrm{OH}) 2 *$ Sat. $\mathrm{Ca}(\mathrm{OH}) 2$

Figure 12. Average data of 3 sample sets of corrosion potential ( $m V$ SCE) verses time for stainless steel plates in testing solutions with and without addition of $0.5 \mathrm{~N} \mathrm{NaCl}$. 


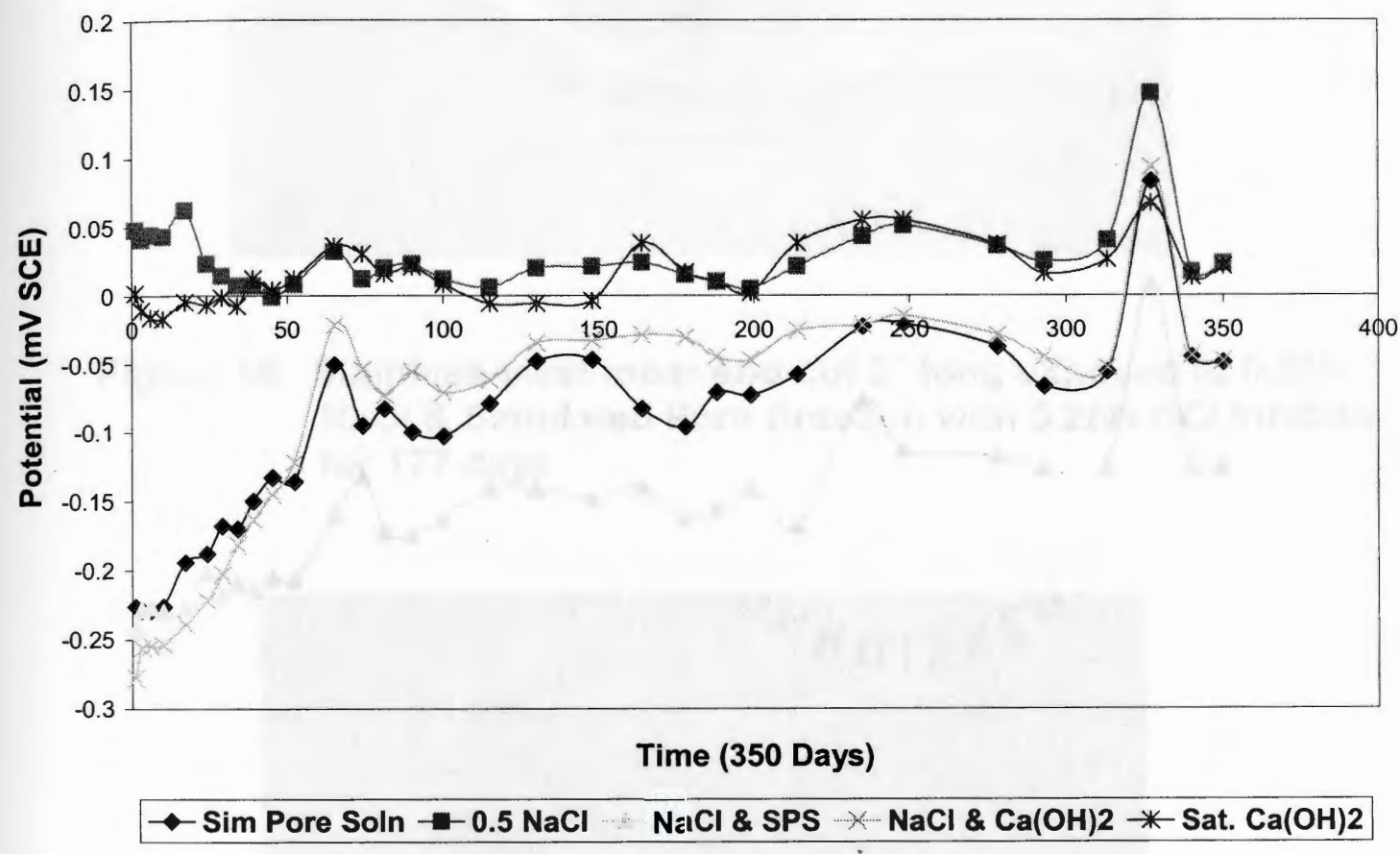

Figure 13. Average data of 3 sample sets of corrosion potential ( $\mathrm{mV} \mathrm{SCE}$ ) verses time for stainless steel plates in testing solutions with and without addition of $0.5 \mathrm{~N} \mathrm{NaCl}, 5 \mathrm{gm}$ of sand added. 


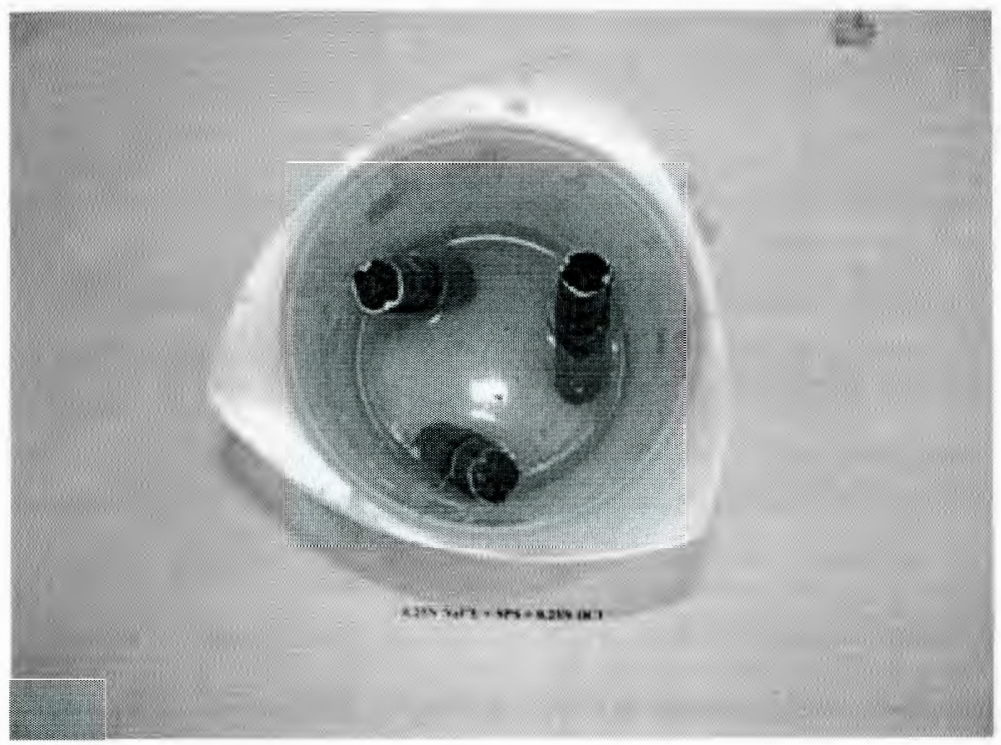

Figure 14. Stainless steel rebar end cut 3" long exposed to $0.25 \mathrm{~N}$ $\mathrm{NaCl} \&$ Simulated Pore Solution with $0.25 \mathrm{~N} \mathrm{DCl}$ Inhibitor for 177 days.

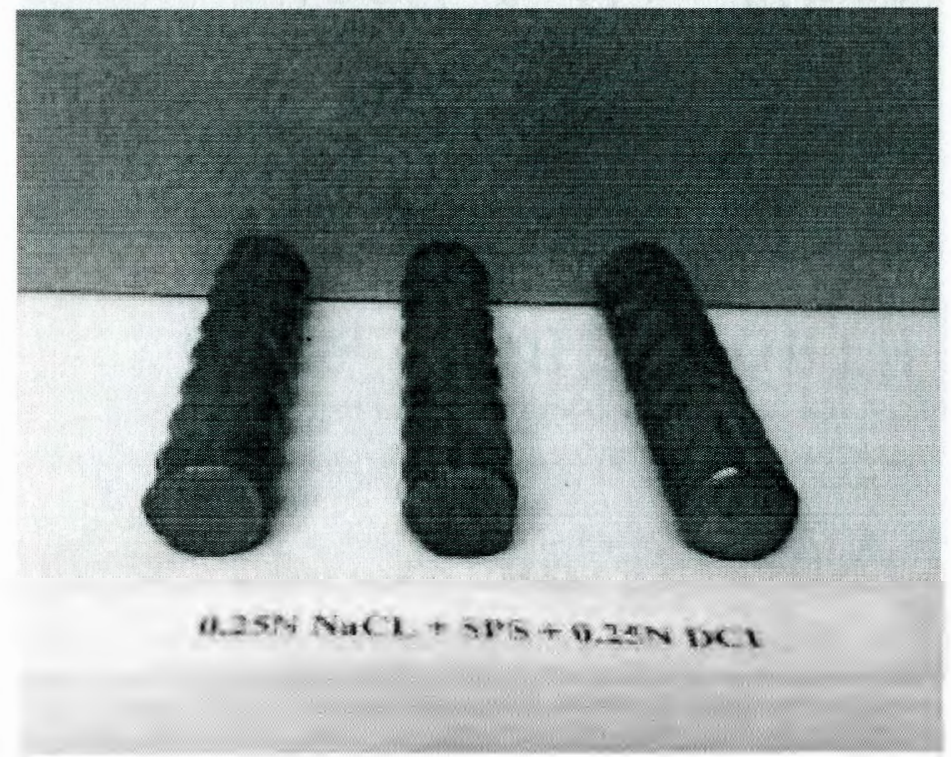

Figure 15. Stainless steel rebar end cut 3 " long exposed to $0.25 \mathrm{~N}$ $\mathrm{NaCl} \&$ Simulated Pore Solution with 0.25N DCI Inhibitor for 177 days. 


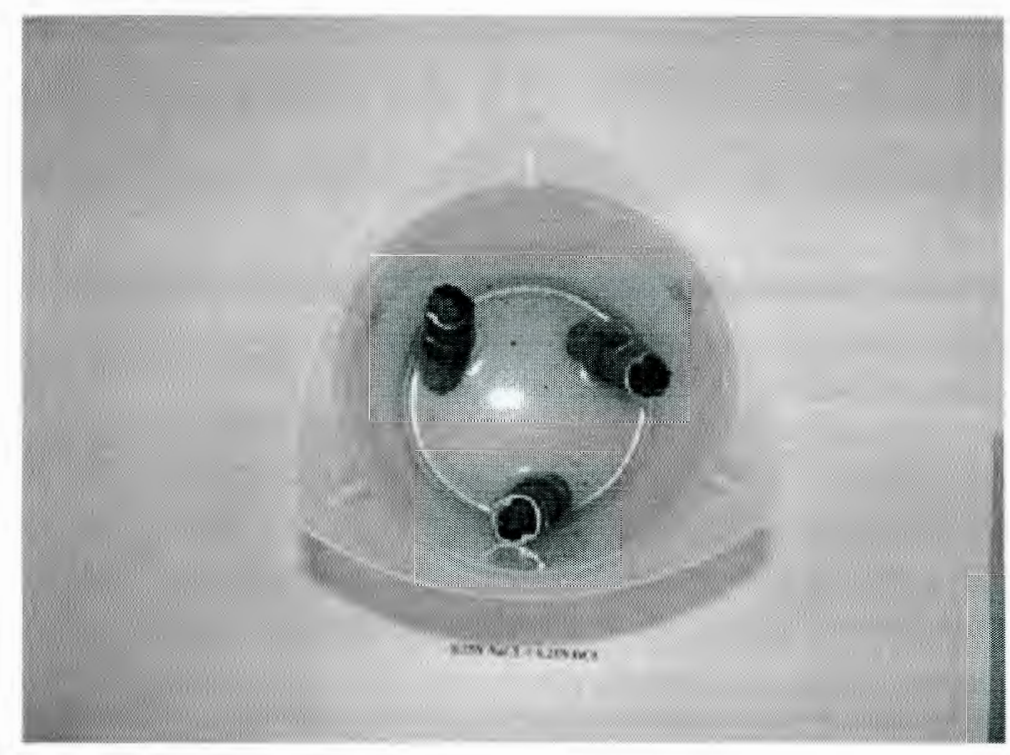

Figure 16. Stainless steel rebar end cut 3" long exposed to $0.25 \mathrm{~N} \mathrm{NaCl}$ with $0.25 \mathrm{~N} \mathrm{DCl}$ Inhibitor for 177 days.

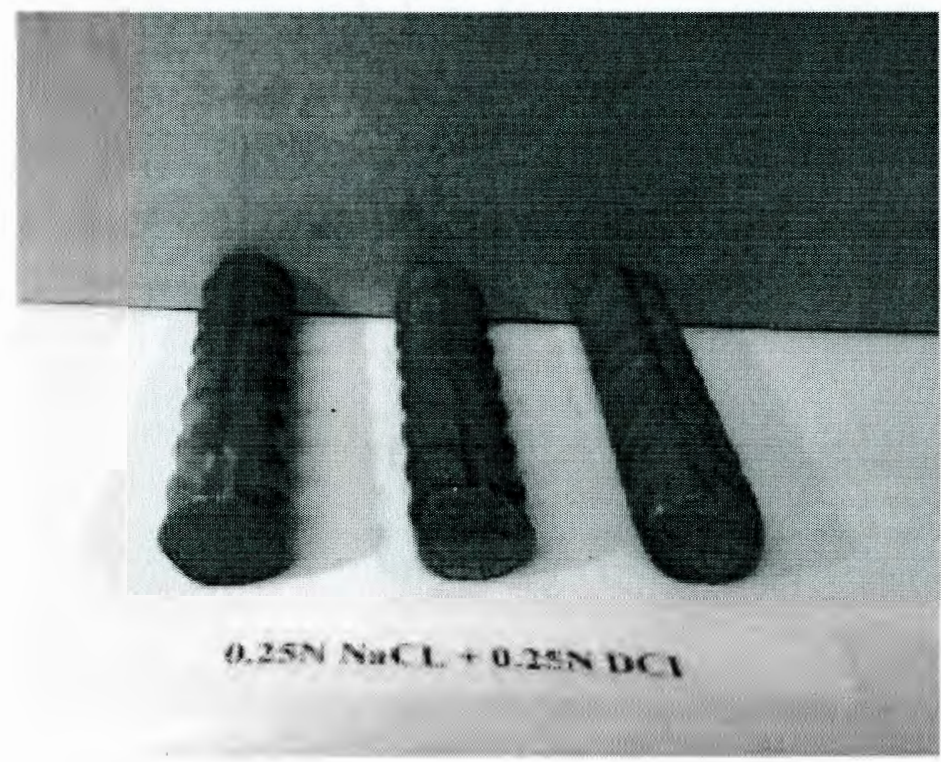

Figure 17. Stainless steel rebar end cut 3" long exposed to $0.25 \mathrm{~N} \mathrm{NaCl}$ with $0.25 \mathrm{~N} \mathrm{DCl}$ Inhibitor for 177 days. 


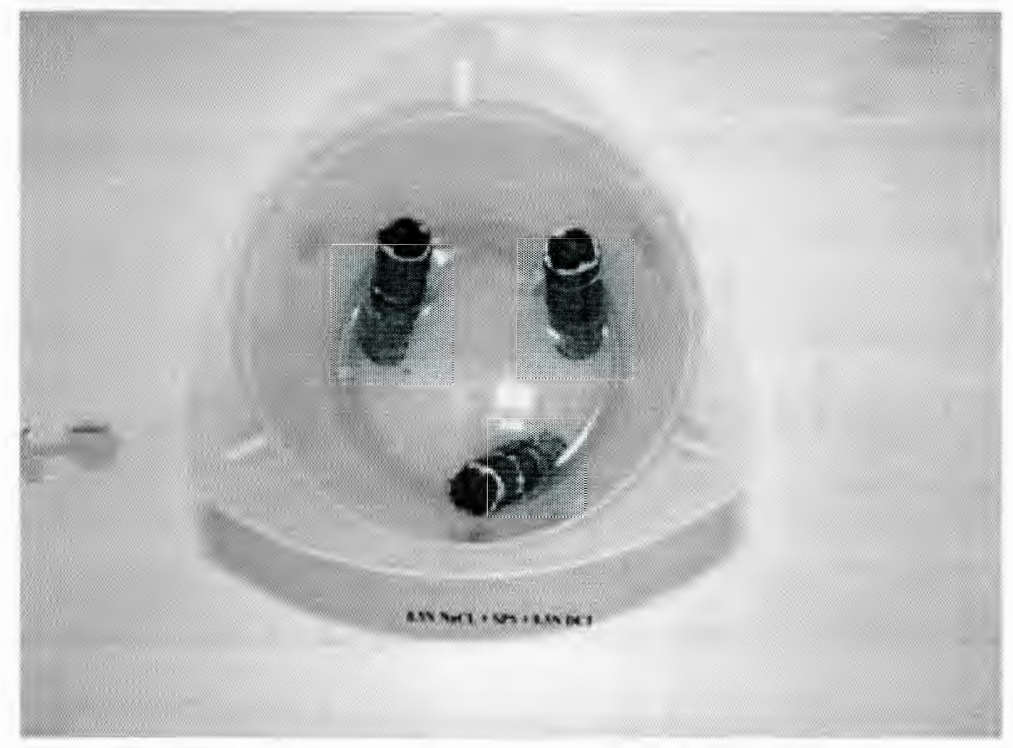

Figure 18. Stainless steel rebar end cut 3" long exposed to $0.5 \mathrm{~N}$ $\mathrm{NaCl} \&$ Simulated Pore Solution with $0.5 \mathrm{~N} \mathrm{DCI}$ Inhibitor for 177 days.

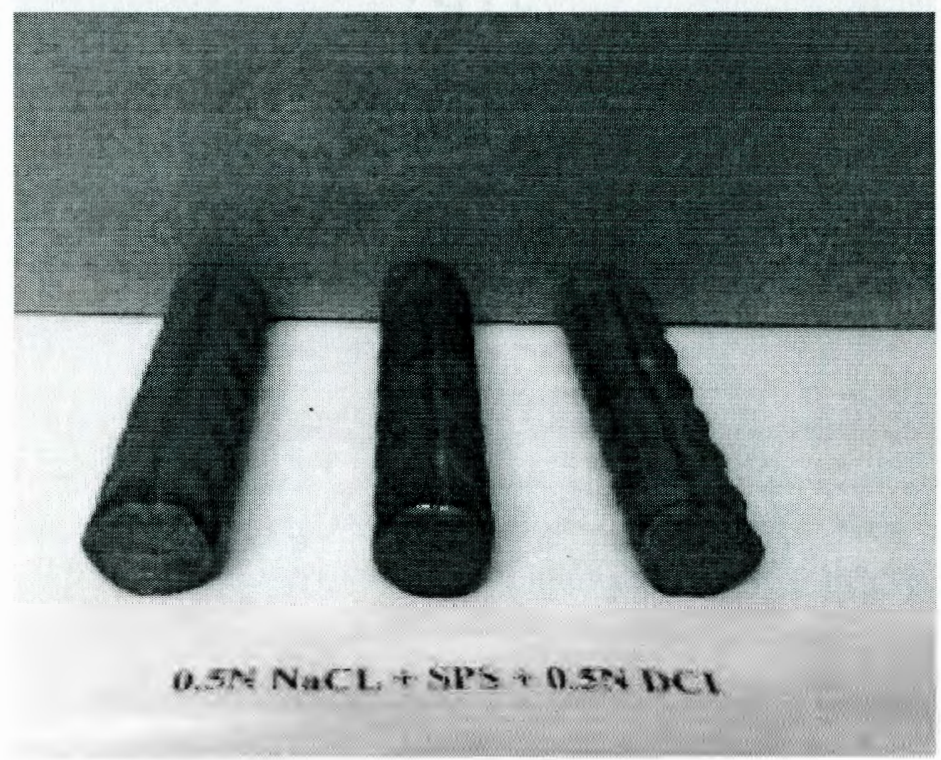

Figure 19. Stainless steel rebar end cut 3" long exposed to $0.5 \mathrm{~N}$ $\mathrm{NaCl} \&$ Simulated Pore Solution with 0.5N DCI Inhibitor for 177 days. 


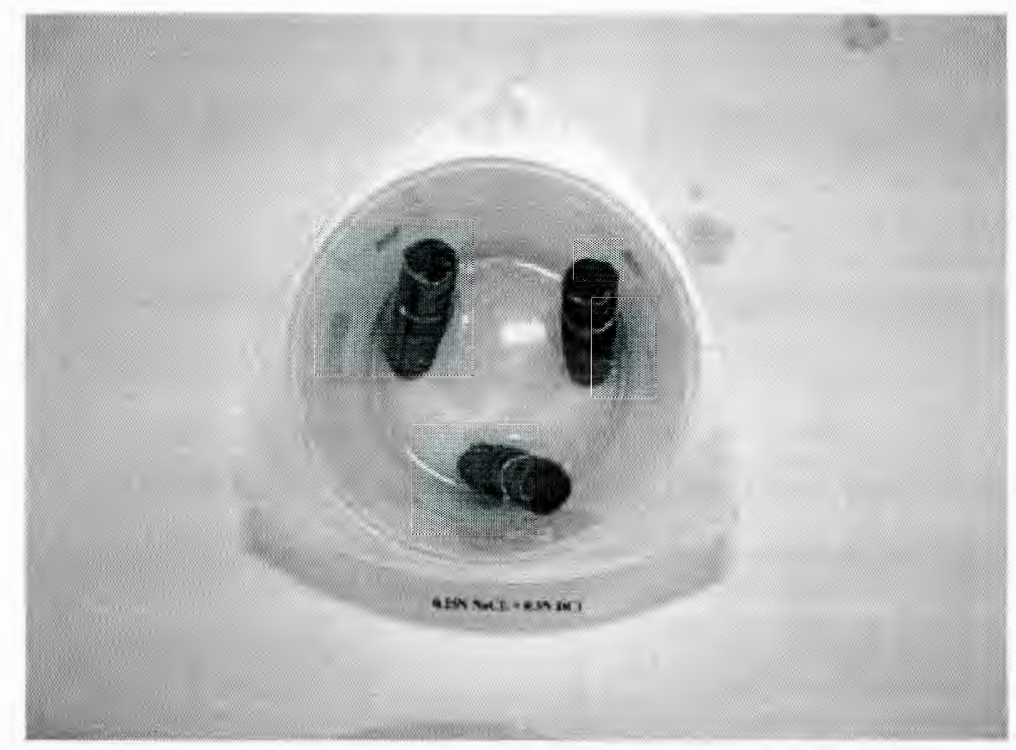

Figure 20. Stainless steel rebar end cut 3" long exposed to $0.25 \mathrm{~N} \mathrm{NaCl}$ with $0.5 \mathrm{~N} \mathrm{DCl}$ Inhibitor for 177 days.

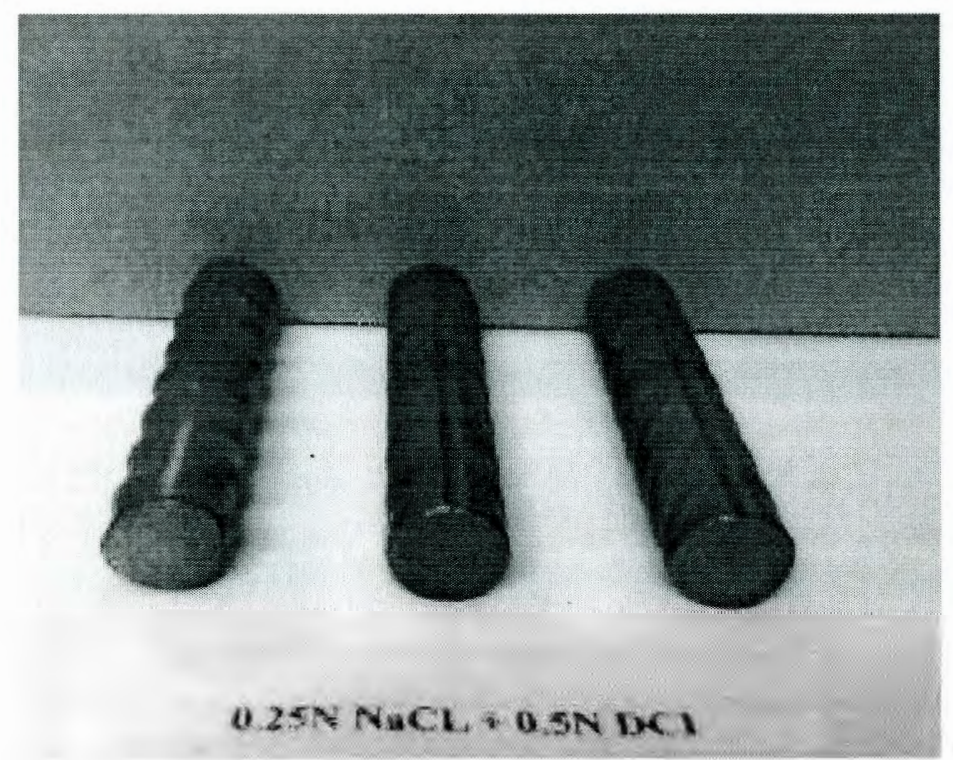

Figure 21. Stainless steel rebar end cut 3" long exposed to $0.25 \mathrm{~N} \mathrm{NaCl}$ with $0.5 \mathrm{~N} \mathrm{DCl}$ Inhibitor for 177 days. 


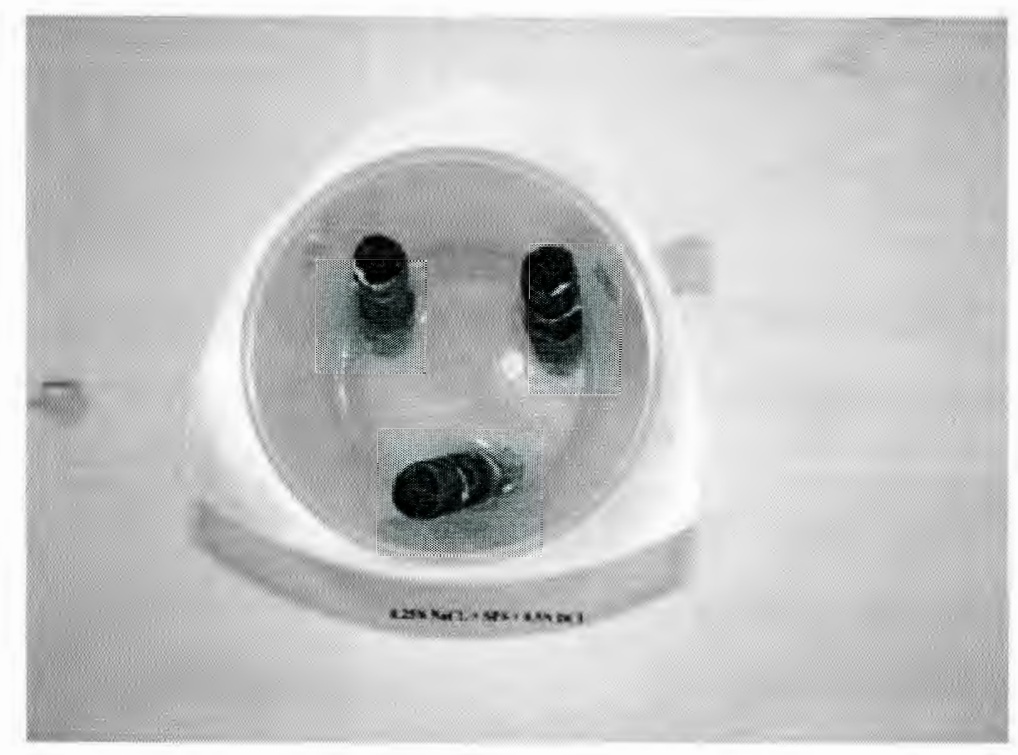

Figure 22. Stainless steel rebar end cut 3" long exposed to $0.25 \mathrm{~N}$ $\mathrm{NaCl} \&$ Simulated Pore Solution with 0.5N DCl Inhibitor for 177 days.

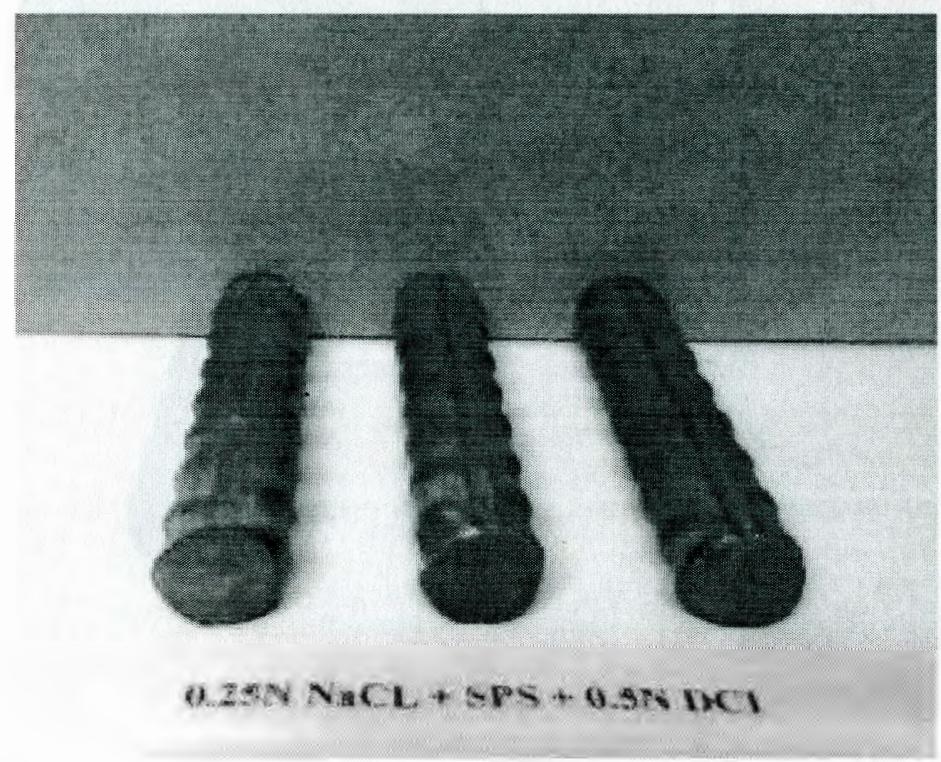

Figure 23. Stainless steel rebar end cut 3 " long exposed to $0.25 \mathrm{~N}$ $\mathrm{NaCl} \&$ Simulated Pore Solution with $0.5 \mathrm{~N} \mathrm{DCI}$ Inhibitor for 177 days. 


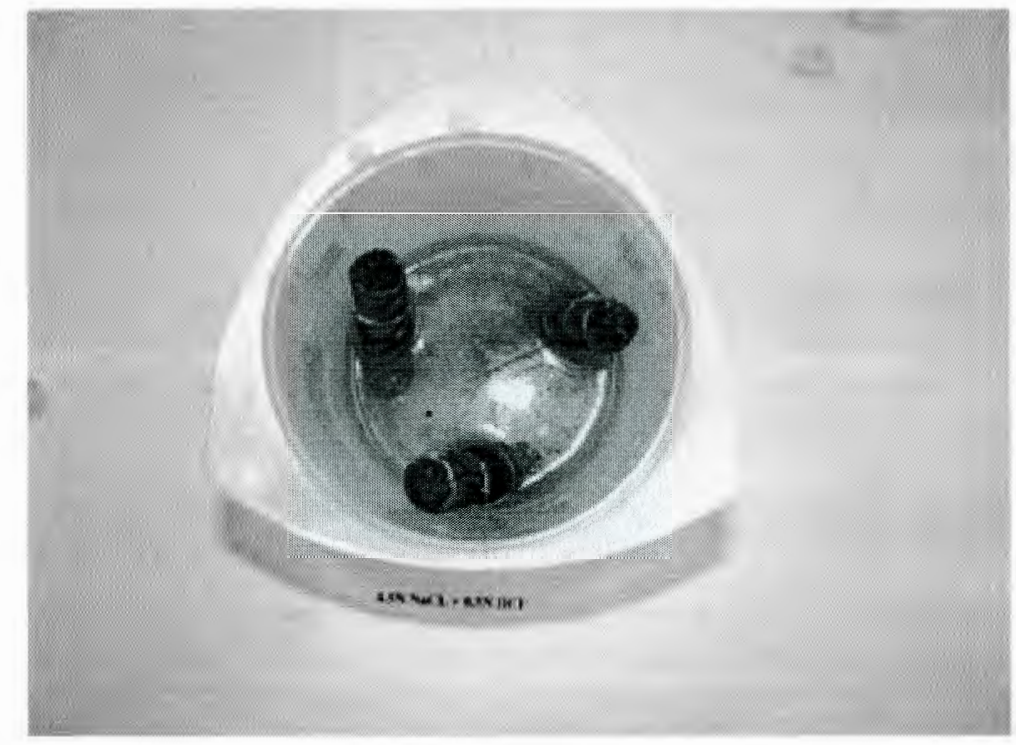

Figure 24. Stainless steel rebar end cut 3" long exposed to $0.5 \mathrm{~N} \mathrm{NaCl}$ with $0.5 \mathrm{~N} \mathrm{DCl}$ Inhibitor for 177 days.

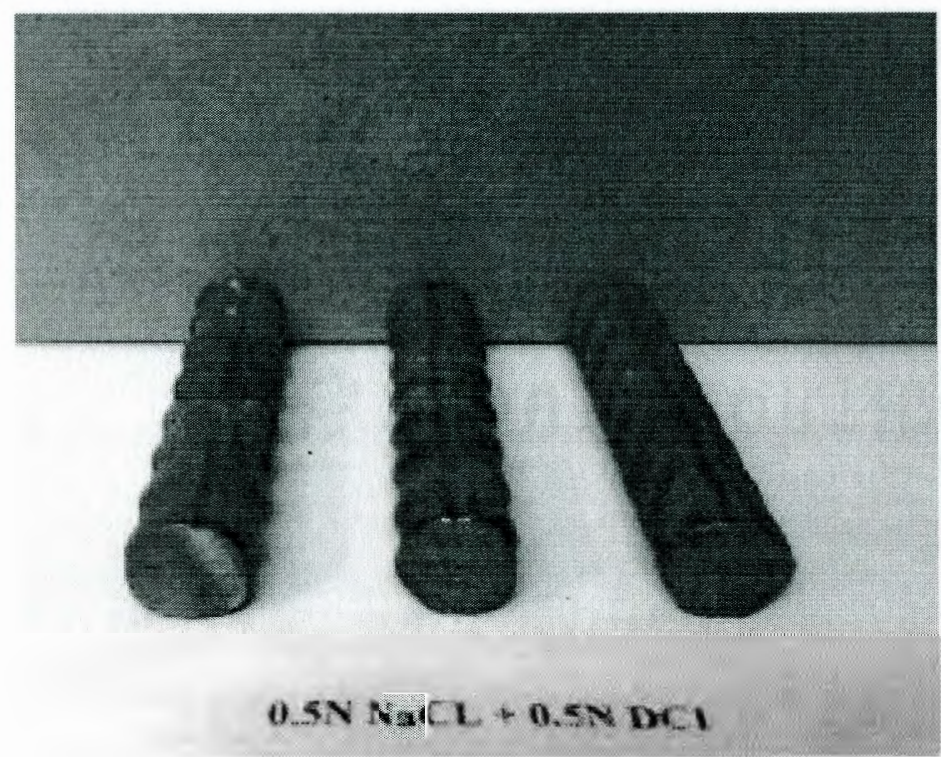

Figure 25. Stainless steel rebar end cut 3" long exposed to $0.5 \mathrm{~N} \mathrm{NaCl}$ with $0.5 \mathrm{~N} \mathrm{DCl}$ Inhibitor for 177 days. 


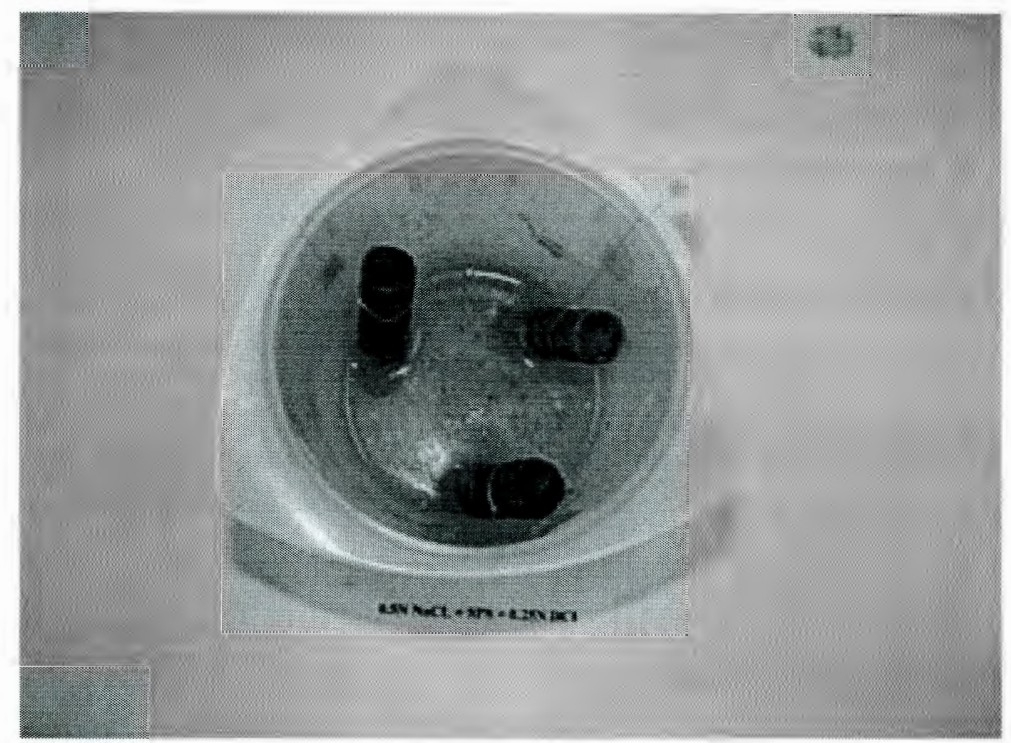

Figure 26. Stainless steel rebar end cut 3" long exposed to $0.5 \mathrm{~N}$ $\mathrm{NaCl} \&$ Simulated Pore Solution with $0.25 \mathrm{~N} \mathrm{DCl}$ Inhibitor for 177 days.

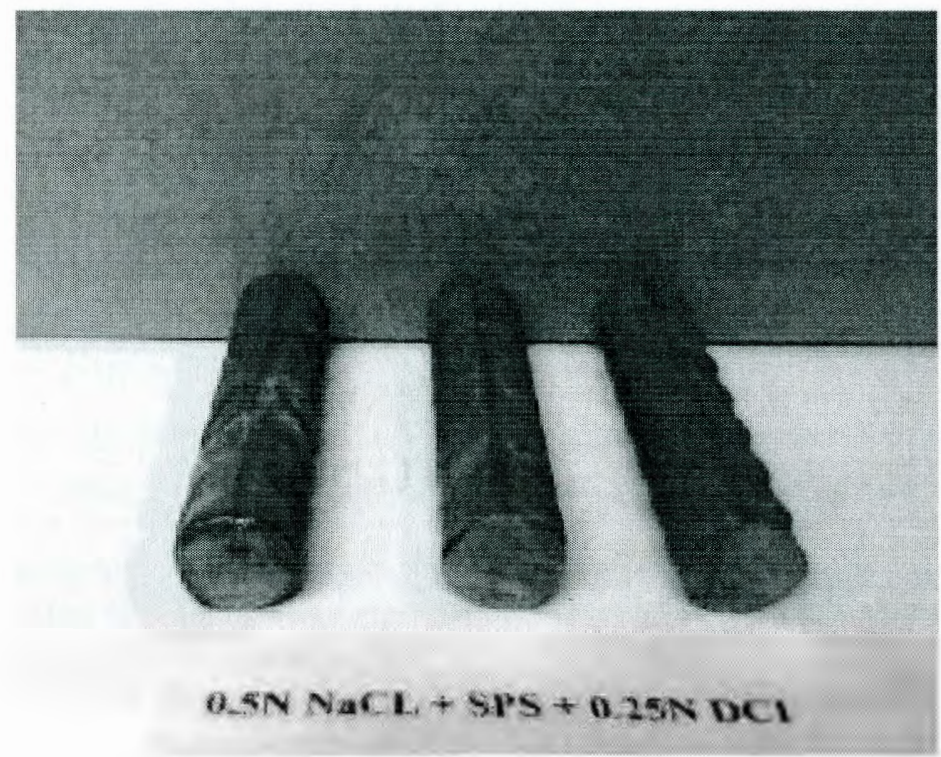

Figure 27. Stainless steel rebar end cut 3" long exposed to $0.5 \mathrm{~N}$ $\mathrm{NaCl} \&$ Simulated Pore Solution with 0.25N DCl Inhibitor for 177 days. 


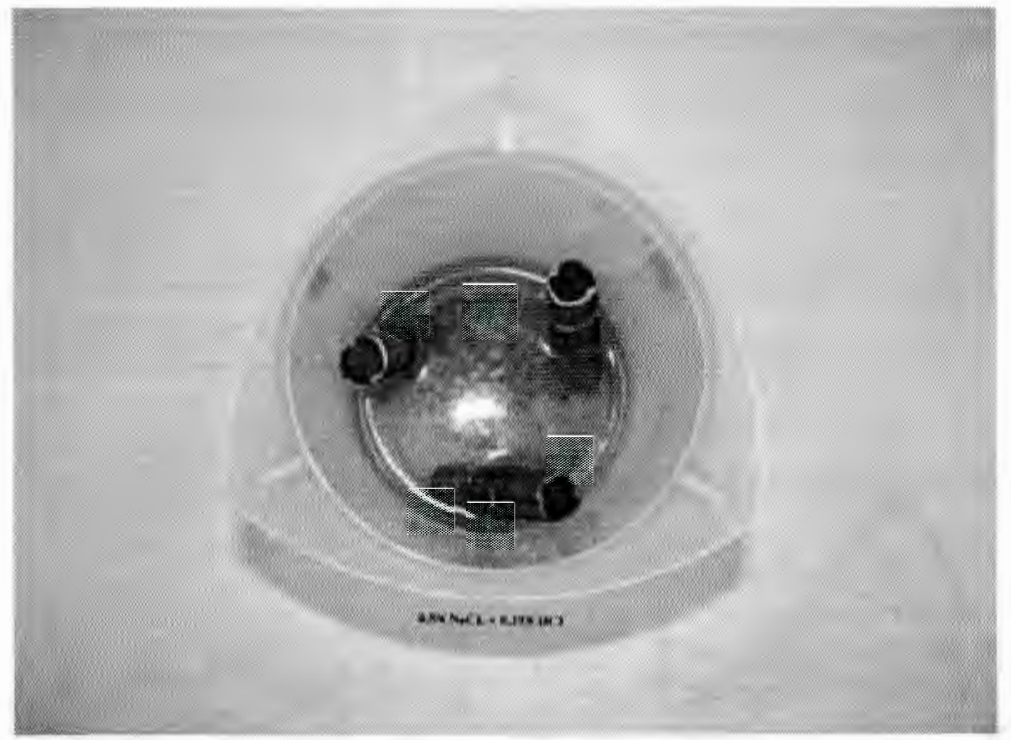

Figure 28. Stainless steel rebar end cut 3" long exposed to $0.5 \mathrm{~N} \mathrm{NaCl}$ with $0.25 \mathrm{~N} \mathrm{DCI}$ Inhibitor for 177 days.

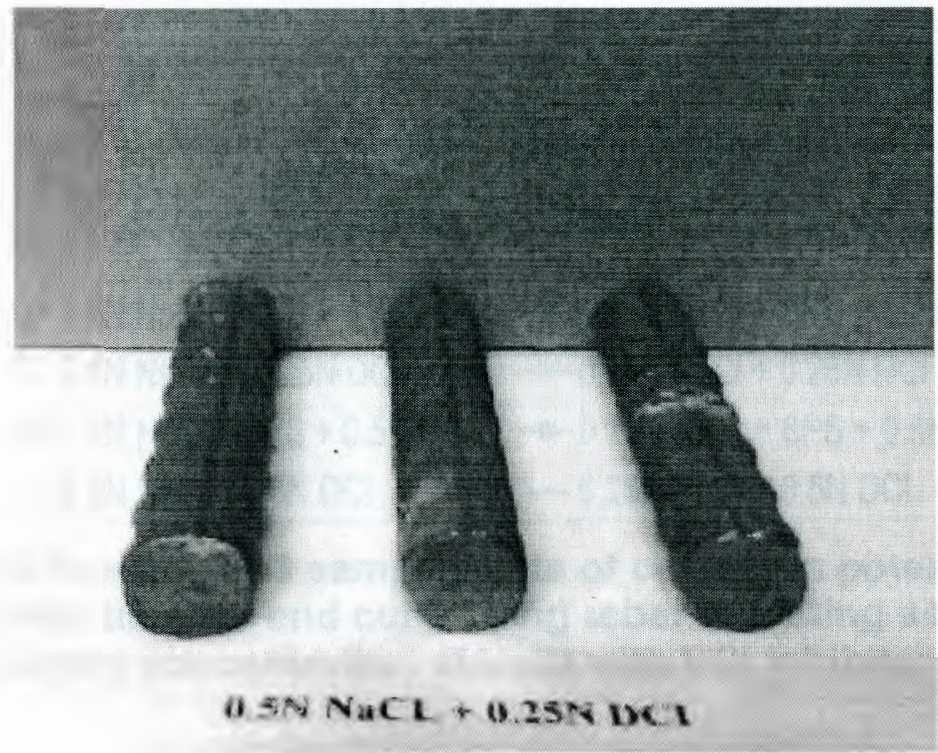

Figure 29. Stainless steel rebar end cut 3" long exposed to $0.5 \mathrm{~N}$ $\mathrm{NaCl}$ with $0.25 \mathrm{~N} \mathrm{DCl}$ Inhibitor for 177 days. 


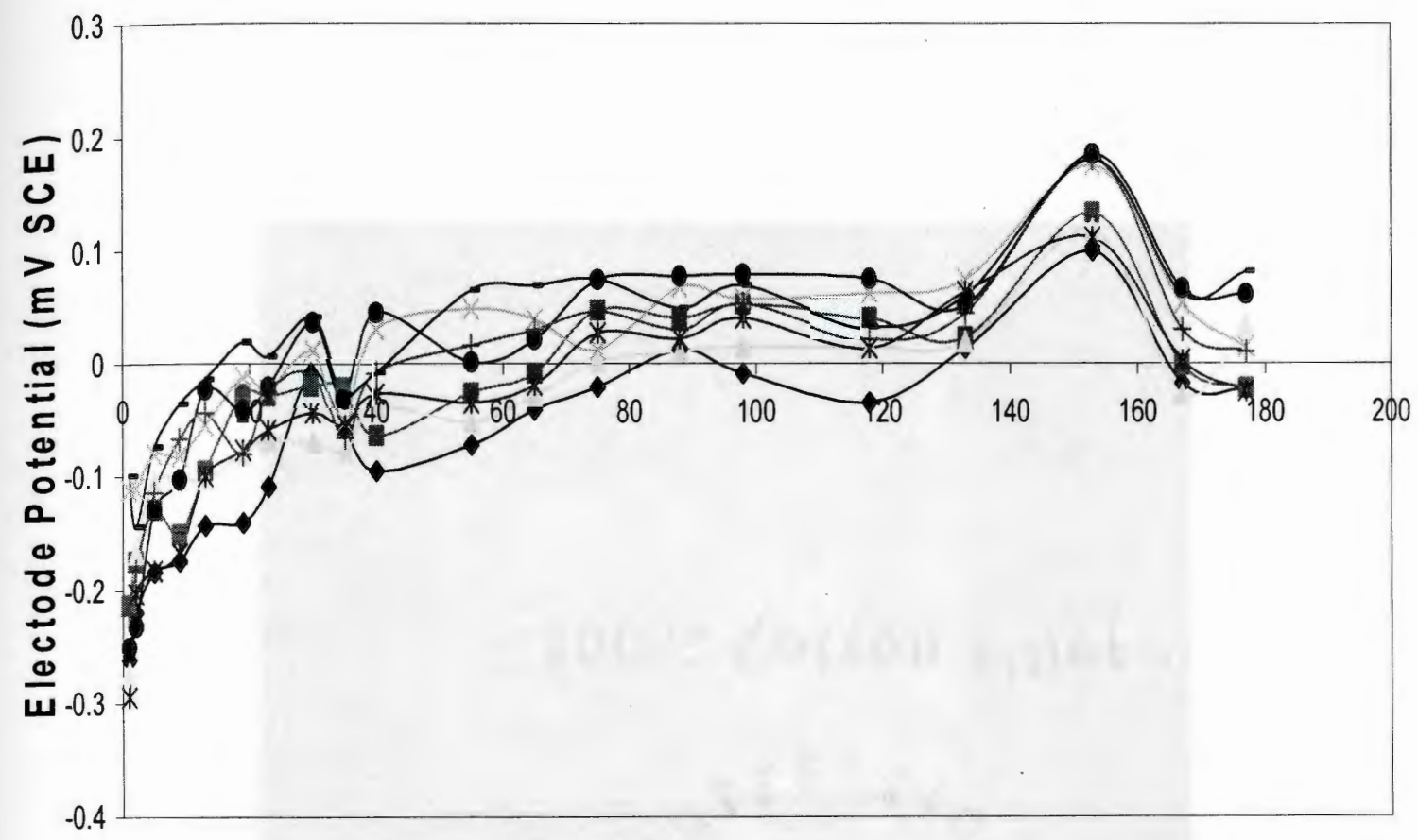

Time (177 Days)

$\begin{array}{cl}\rightarrow-0.5 \mathrm{~N} \mathrm{NaCl}+\text { SPS + 0.25N DCl } & -0.25 \mathrm{~N} \mathrm{NaCl}+\text { SPS + } 0.25 \mathrm{~N} \mathrm{DCl} \\ 0.5 \mathrm{~N} \mathrm{NaCl}+0.25 \mathrm{~N} \mathrm{DCl} & * 0.25 \mathrm{~N} \mathrm{NaCl}+0.25 \mathrm{~N} \mathrm{DCl} \\ -0.5 \mathrm{~N} \mathrm{NaCl}+\text { SPS + 0.5 DCl } & \rightarrow-0.25 \mathrm{~N} \mathrm{NaCl}+\text { SPS + 0.5 DCl } \\ +0.5 \mathrm{~N} \mathrm{NaCl}+0.5 \mathrm{~N} \mathrm{DCl} & -0.25 \mathrm{~N} \mathrm{NaCl}+0.5 \mathrm{~N} \mathrm{DCl}\end{array}$

Figure 30. Data average of 3 samples sets of corrosion potential ( $m$ V SCE) verses time for end cut 3 " long rebar in testing solutions with different concentration of $\mathrm{NaCl}$ with $\mathrm{DCl}$ inhibitor. 


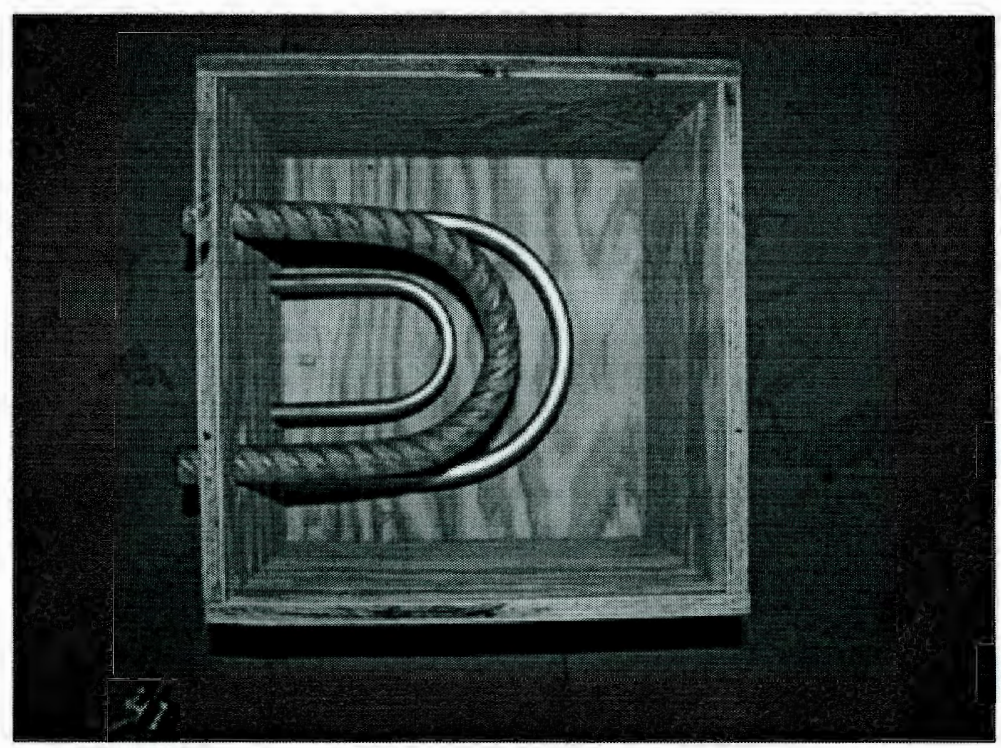

Figure 31. Preparation of modified ASTM G109 test for bend stainless steel rebar samples with 2.5 " , 4.5" and 5.5" Diameter. 


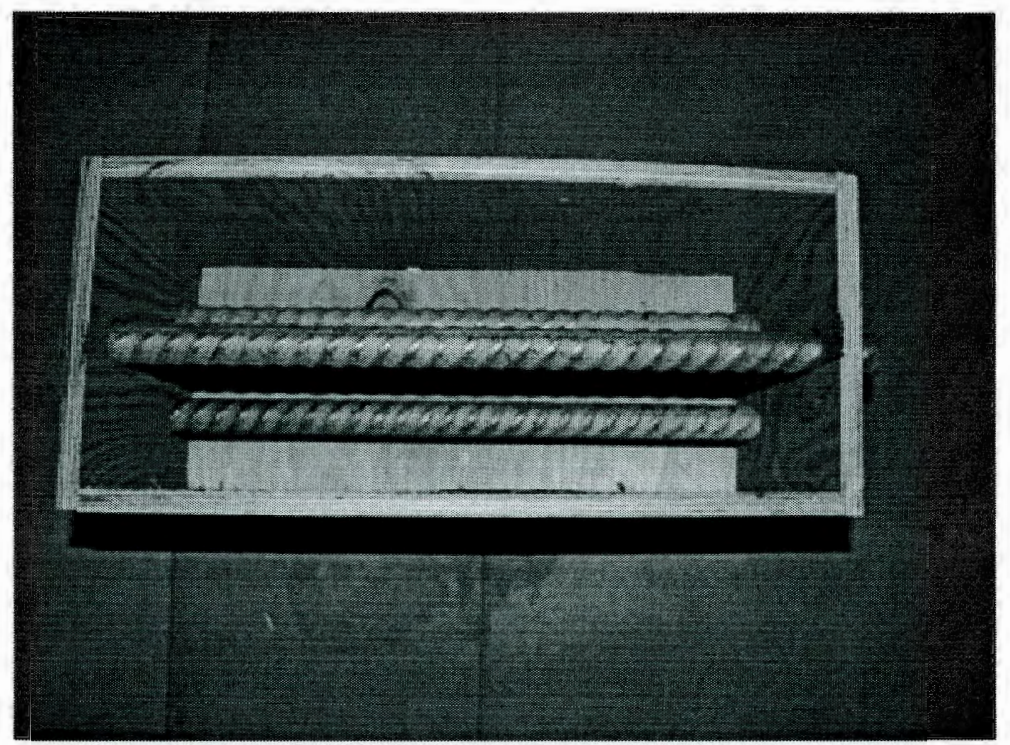

Figure 32. Preparation of ASTM G109 test for stainless steel rebar samples. 


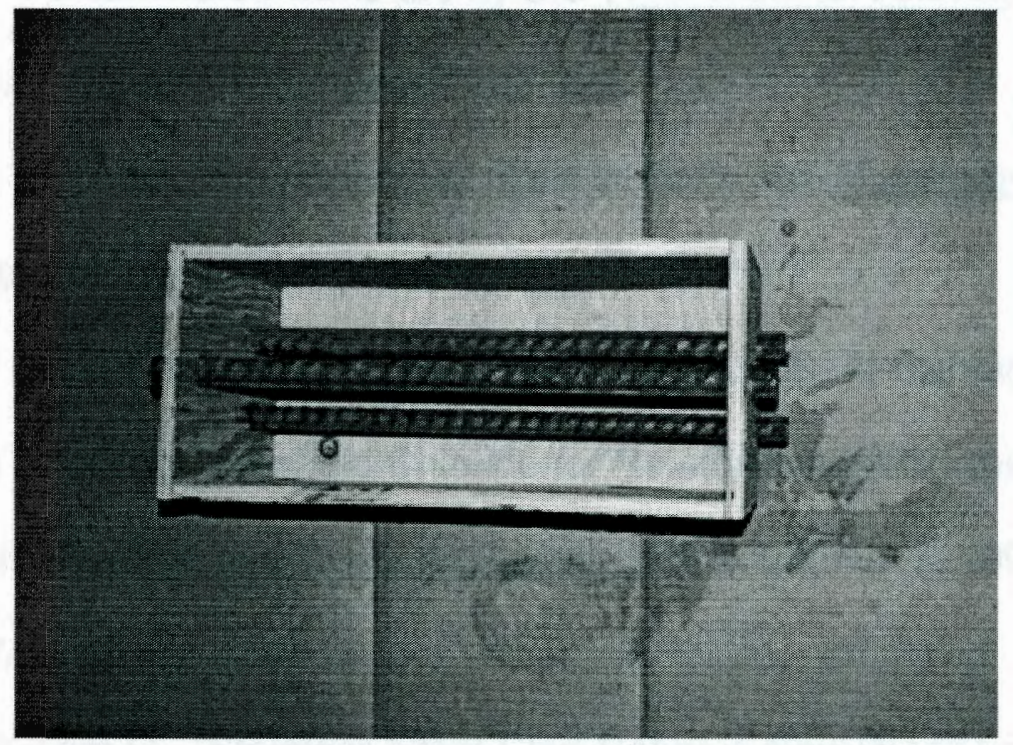

Figure 33. Preparation of ASTM G109 test for conventional steel rebar samples. 


\section{Reference}

1. Lehmann, J. (1987), "Cathodic Protection (Corrosion Control) of Reinforced Structure Using Conductive Coating" Corrosion, Concrete, and Chloride-Steel Corrosion in Concrete: Cause and Restrains, page 129.

2. Gu, P., Elliott S., Et Al., "Study of Corrosion Inhibitor Performance in Chloride Contaminated Concrete by EIS", ACI Material Journal, September-October 1997, pages 353-395.

3. Domain, L., "Corrosion Aspects of Steel in Concrete" Metallurgy and New Materials, Vol. IV, No. 3, 1996, pages 148-161.

4. Hussian S. E., Rasheeduzzafar, A. Al-Musalam, A.S. Al-Gahtani, "Factors Affecting Threshold Chloride for Reinforcement Corrosion in Concrete", Cement and Concrete Research, Vol. 25, No. 7, 1995, pages $1543-1555$.

5. Krizan William G., "Stainless Steel-Clad Rebar is New Weapon in Corrosion War", Materials, Vol.247, No. 3, Jủly 16 2001, page 17.

6. Holm, J. (1987), "Comparison of the Corrosion Potential of Calcium Chloride and a Calcium Nitrate Based Non Chloride Accelerator- A Macrocell Corrosion Approach", Corrosion, Concrete, and ChlorideSteel Corrosion in Concrete: Cause and Restrains, page 40. 
7. Trepanier S. M, B. B. Hope, C. M. Hansson, "Corrosion Inhibitors in Concrete: Part III. Effect on Time to Chloride-Induced Corrosion Initiation and Subsequent Corrosion Rates of Steel in Mortar", $\underline{\text { Cement and }}$ Concrete Research, Vol. 31, 2001, pages 713 -718.

8. Anees. U. Malik, "Corrosion Behavior of Steel in Gulf Seawater Environment" Paper Presented at the WSTA Fourth Gulf Water Conference, Bahrain 13-18 Feb 1999.

9. Ngala V. T., C. L. Page, M. M. Page, "Corrosion Inhibitor Systems for Remedial Treatment of Reinforced Concrete: Part I Calcium Nitrite" Corrosion Science, Vol. 44, 2002, pages 2073-2087.

10. Zumdahl, S.S, Chemistry, D.C. Health and Company, 1989, page 800.

11. Monticelli C, Frognani A, Trabanelli G, Brunoro GA., "Study on the Inhibiting Efficiency of Glycerophosphate-Nitrite Admixtures Against Steel Corrosion Inhibitors" Proceeding of the Eight European Symposium on Corrosion Inhibitors, 1995, pages 609-620.

12. Hachani L, Caprio C. Fiaud, Raharinaivo A, Triki E. "Steel Corrosion in Concrete Deteriorated by Chloride and Sulphates: Electrochemical Study Using Impedance Spectrometry and Stepping Down the Current Methods", Cement Concrete Research, Vol. 22, 1992, pages 56-66.

13. Hachani L, Fiaud C, Triki E, Raharinaivo A, "Characterization of Steel/Concrete Interface by Electrochemical Impedance Spectroscopy", British Corrosion Journal, Vol. 22, No.2, 1994, pages 122-217. 
14. Sagoe, Crentsi KK, Glasser FP, Irvine JTS., "Electrochemical Characteristics of Reinforced Concrete Corrosion as Determined by Impedance Spectroscopy", British Corrosion Journal, Vol. 27, No. 2, 1992, pages $113-118$.

15. Feliu V, Gonzalez JA, Andrade C, Feliu S., "Equivalent Circuit for Modeling the Steel Concrete Interface: Experimental Evidence and Theoretical Predictions", Corrosion Science, Vol. 40, No. 6, 1998, pages $973-975$.

16. Li Zongjin, Baoguo Ma, Jun Peng, Meng Qi, "The Microstructure and Sulfate Resistance Mechanism of High Performance Concrete Containing DCI", Cement and Concrete Composites, Vol. 22, 2000, pages 369-377.

17. Dry C. M., M. J. T. Corsaw, "A Time-Release Technique for Corrosion Prevention", Cement and Concrete Research, Vol. 28, No. 8, 1998, pages $133-1140$

18. Tritthart J., P. F. G. Banfill, "Nitrite Binding in Cement", Cement and Concrete Research, Vol. 31, 2001, pages 1093-1100.

19. Glass Gareth K., "Developments in Cathodic Protection Applied to Reinforced Concrete", Journal of Material in Civil Engineering, September/ October 2001, pages 396-398.

20. Magee John H., Raymond E. Schnell, "Stainless Steel Rebar", Advanced Materials \& Processes, Vol. 160, No. 10, October 2002, pages $43-45$. 
21. Berke, Neal S, Donald W. Pfeifer, Thomas G. Weil, "Protection Against Chloride Induced Corrosion: A Review of Data and Economics on Microsilica and Calcium Nitrite", Concrete International, Vol. 10, No, 12,1988 , pages $45-55$.

22. Locke, Carl E., "Corrosion of Steel in Portland Cement Concrete:

Fundamental Studies", Chaker, Victor, Corrosion Effect of Stray and

Techniques for Evaluating Corrosion of Rebar in Concrete, Vol. 906, pages $5-13,1985$, Philadelphia, PA, American Society for Testing and Materials, 1986.

23. Daily Steven F., Kevin Kendell, "Cathodic Protection for New Concrete", Concrete International, June 1999, pages 63-68.

24. Hansson, C. M., L. Mammoliti, B. B. Hope, "Corrosion Inhibitors in Concrete - Part I: The Principles", Cement and Concrete Research, Vol. 28, No. 12,1998 , pages $1775-1781$.

25. Chen W. F. The Civil Engineering Hand Book, 1995 CRC Press. pages $1218-1219$.

26. Ramasubramanian M., B. S. Haran, S. Popova, B. N. Popov, M F. Petrou, R. E. White. "Inhibiting Action of Calcium Nitrite on Carbon Steel Rebars", Journal of Material in Civil Engineering, January / February 2001, pages 10-17.

27. Berke, NS. Rosenberg, N., "Technical Review of Calcium Nitrite Corrosion Inhibitor in Concrete", Transportation Research Record, 1990, pages $12-27$. 
28. Li L. A. A. Sagues, "Chloride Corrosion Threshold of Reinforcing steel In Alkaline Solution-Open Circuit Immersion Tests", Corrosion Science, Vol. 57, No. 1 January 2001, pages 19-28.

29. Adam Neville "What Everyone Who is in Concrete Should Know About Concrete" Concrete International, April 1999, pages 57-61.

30. GonZalez J. A., M. Benito, S. Feliu, P Rodriguez, C. Andrade, "Suitability of Assessment Methods for Identifying Active and Passive Zones in Reinforced Concrete", Corrosion Vol. 51, No. 2, Feb. 1995 pages $145-152$. 


\section{Bibliography}

Adam Neville, "What Everyone Who is in Concrete Should Know About Concrete", Concrete International, April 1999, pages 57-61.

Andrade, C., A. Arteaga, C. Lopez-Hombrados, Vazquez. "Testes on Bond of Galvanized Rebar and Concrete Cured in Seawater", Journal of Material in Civil Engineering, September / October 2001, pages 319-324.

Anees U. Malik, "Corrosion Behavior of Steel in Gulf Seawater Environment", Paper Presented at the WSTA Fourth Gulf Water Conference, Bahrain, 13-18 Feb 1999.

Baptista Walmar, Gutemberg Pimenta, "Cathodic Protection Against Crevice Corrosion of High Alloy Steel in Seawater", Material Performance, Vol. 34 No. 10, Oct. 1995 pages 29-32.

Bastidas J. M., J. L. Polo, C. L. Torres, E. Cano, "A Stochastic Approach to Study Localized Corrosion of AISI 304L and AISI 316L Stainless Steels as a Function of Potential Scan Rate", Corrosion Science, Vol. 57, No. 8, August 2001, pages 666-669.

Belaid F., G. Arliguie, R. Francois, "Effect of Bars Properties on Band Strength of Galvanized Reinforcement", Journal of Material in Civil Engineering, November / December 2001, pages 454-458.

Berke Neal S, Donald W. Pfeifer, Thomas G. Weil, "Protection Against Chloride Induced Corrosion: A Review of Data and Economics on Microsilica and Calcium Nitrite", Concrete International, Vol. 10, No. 12, 1988, pages $45-55$.

Berke N. S., Rosenberg N., "Technical Review of Calcium Nitrite Corrosion Inhibitor in Concrete", Transportation Research Record, 1990, pages 12-27.

Callaghan B. G., "The Performance of a 12\% Chromium Steel in Concrete in Severe Marine Environment", Corrosion Science, Vol. 35, No.5-8, 1993, pages $1535-1541$.

Chen, W. F. The Civil Engineering Hand Book, 1995 CRC Press. pages $1218-$ 1219.

Cochrane D.J., "Stainless Steel Reinforcement for Durability in Concrete Structures", Nuclear Energy, Vol. 37, No. 5, Oct. 1998, pages 331-335. 
Daily Steven F., Kevin Kendell, "Cathodic Protection for New Concrete", Concrete International, June 1999, pages 63-68.

Domain, L., "Corrosion Aspects of Steel in Concrete", Metallurgy and New Materials, Vol. IV, No. 3, 1996, pages 148-161.

Dry, C. M., M. J. T. Corsaw, "A Time-Release Technique for Corrosion Prevention", Cement and Concrete Research, Vol. 28, No. 8, 1998, pages $1133-1140$

Emmons, Ph., Vaysburd, A.M., "Corrosion Protection and Concrete Repair: Myth and Reality", Concrete International, Vol. 19, No. 3, March 1997, pages 47 -56.

Erlemann Gustav G., "Steel Reinforcing Bar Specifications in Old Structures", Concrete International, April 1999, pages 49-50.

Feliu V., Gonzalez J. A, Andrade C., Feliu S., "Equivalent Circuit for Modeling the Steel Concrete Interface: Experimental Evidence and Theoretical Predictions", Corrosion Science, Vol. 40, No. 6, 1998, pages 973 - 975.

Flint, G. N., Cox R. N., "The Resistance of Stainless Steel Partly Embedded in Concrete to Corrosion by Seawater", Magazine of Concrete Research, Vol. 40, No.142, 1988, Pages13-27.

Gartland P.O., S. Valen, "Crevice Corrosion of High Alloyed Stainless Steels in Chlorinated Seawater, Part II, Aspects of the Mechanism", paper presented at NACE, Corrosion Vol. 91, preprint No. 511, 1991.

Glass, Gareth K., "Developments in Cathodic Protection Applied to Reinforced Concrete", Journal of Material in Civil Engineering, September / October 2001, pages 396-398.

GonZalez J. A., M. Benito, S. Feliu, P Rodriguez, C. Andrade., "Suitability of Assessment Methods for Identifying Active and Passive Zones in Reinforced Concrete", Corrosion, Vol. 51, No. 2, Feb. 1995, pages 145-152.

Gu, P., Elliott S., Et Al., "Study of Corrosion Inhibitor Performance in Chloride Contaminated Concrete by EIS", ACI Material Journal, SeptemberOctober 1997, pages 353-395.

Hachani L., Caprio C. Fiaud, Raharinaivo A, Triki E., "Steel Corrosion in Concrete Deteriorated by Chloride and Sulphates: Electrochemical Study Using Impedance Spectrometry and Stepping Down the Current Methods", Cement Concrete Research, Vol. 22, 1992, pages 56-66. 
Hachani L, Fiaud C., Triki E., Raharinaivo A., "Characterization of Steel/Concrete Interface by Electrochemical Impedance Spectroscopy" British Corrosion Journal, Vol. 22, No.2, 1994, pages 122-217.

Hansson, C. M., L. Mammoliti, B. B. Hope, "Corrosion Inhibitors in Concrete: Part I: The Principles", Cement and Concrete Research, Vol. 28, No. 12, 1998, pages $1775-1781$.

Holm, J. (1987). "Comparison of the Corrosion Potential of Calcium Chloride and a Calcium Nitrate Based Non Chloride Accelerator- A Macrocell Corrosion Approach", Corrosion, Concrete, and Chloride-Steel Corrosion in Concrete: Cause and Restrains, page 40.

Hussian S. E., Rasheeduzzafar, A. Al-Musalam, A.S. Al-Gahtani, "Factors Affecting Threshold Chloride for Reinforcement Corrosion in Concrete", Cement and Concrete Research, Vol. 25, No. 7, 1995, pages 1543 -1555.

Iskander S. K., R. K. Nanstad, G. C. Robinson, C. B. Oland, "An Experimental Study of the Effect of Stainless Steel Cladding on the Structure Integrity of Flawed Steel Plated in Bending", American Society of Mechanical Engineers, Vol.167, July 23-27 1989, pages 87-92.

Jakobsen P. T., E. Maahn, "Temperature and Potential Dependence of Crevice Corrosion of AISI 316 Stainless Steel”, Corrosion Science, Vol. 43, 2001, pages 1693-1709.

Kain R. M., J. W. Oldfield, "Crevice Corrosion Behavior of Stainless Steel in Chloride and Sulfate Containing Water", paper presented at NACE, Corrosion Vol. 90, preprint No. 384, 1990.

Kehler B.A., G. O. llevbare, J.R. Sculy, "Crevice Corrosion Stabilization and Repassivation Behavior of Alloy 625 and Alloy 22" Corrosion, Vol. 57 No. 12, Dec. 2001, pages 1042-1065.

Krantz Brad, "Galvanic Effects Accelerate Crevice Corrosion of Type 316L SS Flanges coupled to $6 \%$ Mo Alloy", Material Performance Vol. 38, No. 6, June, 1999, pages 72-74.

Krizan William G., "Stainless Steel-Clad Rebar is New Weapon in Corrosion War", Materials, Vol.247, No. 3, July 16 2001, page 17.

Laycock N.J, J. Stewart, R.C. Newman, "The Initiation of Crevice Corrosion in Stainless Steels", Corrosion, Vol. 39, No. 10-11, 1997, pages 1791-1809. 
Lee T.S., R. M. Kain, "Factors Influencing the Crevice Corrosion Behavior of Stainless Steel in Seawater", paper presented at NACE Corrosion Vol. 83, preprint no. 69, 1983.

Lehmann, J. (1987) "Cathodic Protection (Corrosion Control) of Reinforced Structure Using Conductive Coating", Corrosion, Concrete, and ChlorideSteel Corrosion in Concrete: Cause and Restrains, page 129.

Li L., A. A. Sagues, "Chloride Corrosion Threshold of Reinforcing steel In Alkaline Solution-Open Circuit Immersion Tests", Corrosion Science, Vol. 57, No. 1, January 2001, pages 19-28.

Li Zongjin, Baoguo Ma, Jun Peng, Meng Qi, "The Microstructure and Sulfate Resistance Mechanism of High Performance Concrete Containing DCl", Cement and Concrete Composites, Vol. 22, 2000, pages 369-377.

Locke, Carl E., "Corrosion of Steel in Portland Cement Concrete: Fundamental Studies", Chaker, Victor, Corrosion Effect of Stray and Techniques for Evaluating Corrosion of Rebar in Concrete, Vol. 906, pages 5-13, 1985, Philadelphia, PA, American Society for Testing and Materials, 1986.

Magee John H., Raymond E. Schnell, "Stainless Steel Rebar" Advanced Materials \& Processes, Vol. 160, No. 10, October 2002, pages $43-45$.

Mauer J. R., "Results of Seven Years Exposure of Dissimilar Metal Crevice Assemblies in Filtered Seawater", paper presented at NACA Corrosion/93, Preprint No. 490, 1993, and Materials Performance, Vol. 33, No. 4, 1994. pages 51.

McDonald David B., Yash Paul Virmani, Donald F. Pfeifer, "Testing the Performance of Copper-clad Reinforcing Bars", Concrete International, November 1996, Pages 39-43.

McDonald D. B., M. R. Sherman, D. W. Pfeifer, Y. P. Vermani, "Stainless steel Reinforcing as Corrosion Protection", Concrete International, Vol. 17, No. 5, May, 1995, pages 65-70.

Monticelli C, Frognani A, Trabanelli G, Brunoro GA. "Study on the Inhibiting Efficiency of Glycerophosphate-Nitrite Admixtures Against Steel Corrosion Inhibitors", Proceeding of the Eight European Symposium on Corrosion Inhibitors, 1995, pages 609-620.

Ngala V. T., C. L. Page, M. M. Page, "Corrosion Inhibitor Systems for Remedial Treatment of Reinforced Concrete. Part I Calcium Nitrite", Corrosion Science, Vol. 44, 2002, pages 2073-2087. 
Norman R. C., "Understanding the Corrosion of Stainless Steel", Corrosion, Vol.57, No. 12, Dec. 2001, pages 1030-1041.

Oldfield J. W., "Crevice Corrosion of Stainless Steel in Seawater", ACOM report No. 1-1988, Avesta, Sweden, 1988.

Pfeifer Donald W., "High Performance Concrete and Reinforcing Steel With a 100 Years Service Life", PCl Journal, May / June 2000, Pages 46-54.

Poppmeier W. A. H., J. C. Vreugdenburg, "The Manufacture of Stainless Clad Steel", Journal of the South African Institute of Mining and Metallurgy, Vol. 91, No. 12, December 1991, pages 435-439.

Pyc W. A., R. E. Weyers, M. M. Sprinkel, R. M. Weyers, D. W. Mokarem, J. G. Dillard, "Performance of Epoxy-Coated Reinforcing Steel", Concrete International, February 2000, pages 57-61.

Ramasubramanian M., B. S. Haran, S. Popova, B. N. Popov, M F. Petrou, R. E. White., "Inhibiting Action of Calcium Nitrite on Carbon Steel Rebars", Journal of Material in Civil Engineering, January / February 2001, pages 10-17.

Sagoe, Crentsi KK, Glasser FP, Irvine JTS. "Electrochemical Characteristics of Reinforced Concrete Corrosion as Determined by Impedance Spectroscopy", British Corrosion Journal, Vol. 27, No. 2, 1992, pages $113-118$.

Sedriks A. John, "Corrosion of Stainless Steels", New York, NY: John Willy \& Sons. 1996.

Siegwart M., B.J. Mcfarland, J.F. Lyness, A. Abu-Tair, "Application of Inhibitors to Reduce the Hydrogen Uptake of Steel During Electrical Chloride Extraction", Corrosion, Vol. 58, No. 3, March 2002, pages 257-266.

Smith Frank N., Martin Tullmin, "Using Stainless Steel as Long Lasting Rebar Material", Material Performance, Vol. 38, No. 5, May, 1999, pages 72-76.

Steinsmo U, T. Rogne, J. Drugli, "Aspects of Testing and Selecting Stainless Steels for Seawater Applications", Corrosion Science, Vol. 53, No. 12, December 1997, pages 955-964.

Trepanier S. M, B. B. Hope, C. M. Hansson, "Corrosion Inhibitors in Concrete: Part III. Effect on Time to Chloride-Induced Corrosion Initiation and Subsequent Corrosion Rates of Steel in Mortar", Cement and Concrete Research, Vol. 31, 2001, pages 713 -718.

Tritthart J., P. F. G. Banfill, "Nitrite Binding in Cement", Cement and Concrete Research, Vol. 31, 2001, pages 1093-1100. 
Vazquez, E., “Corrosion Inhibitor”, RILEM Report, October 1995, Pages 88 - 94. 14. Berke, N.S., "Corrosion Inhibitors in Concrete", Concrete International, July 1991, Pages 24-27.

Wallen B., "Some Factors Affecting Stainless Steel Corrosion in Seawater", ACOM Report No. 4-1990, Avesta AB, Avesta, Sweden 1990.

Zumdahl, S.S, Chemistry, D.C. Health and Company, 1989, page 800. 